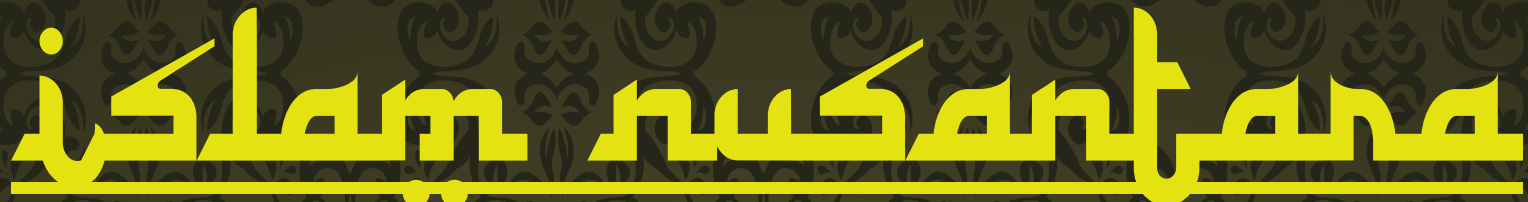

Journal for the Study of Istamic History and Callune

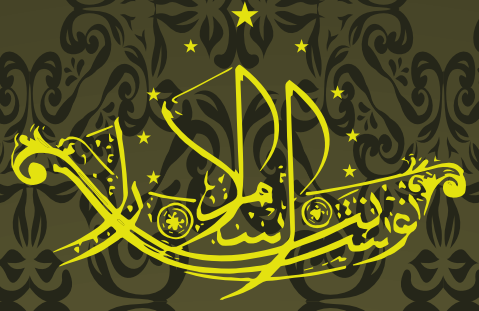

Exploring the Reality and Aspirations of Muslims

The divisions of the Umat in Indonesia

Hisanori Kato

Defending Islam Nusantara at the Frontline

Experiment to shape moderatism among Non-structural

Nahdliyyin Community

Hamdani

Bahasa dan Kekuasaan dalam Historiografi Islam Marshall G.S. Hodgson

Greg soetomo

Keberagamansemu dan Dilema Minoritas

dir Kota Banda Aceh

Teuku Kemal Fasya

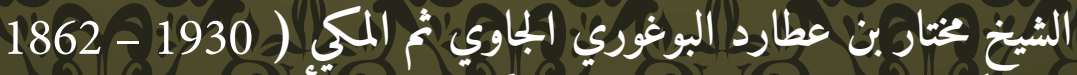

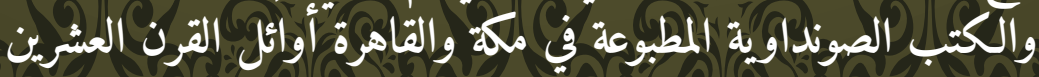

$$
\begin{aligned}
& \text { Ginanjar Sya'ban }
\end{aligned}
$$

\section{Book Review}

Jawa, Islam dan Nusantara:

Memposisikan Agama dalam Keragaman Budaya Riwanto Tirto Sudarmo 


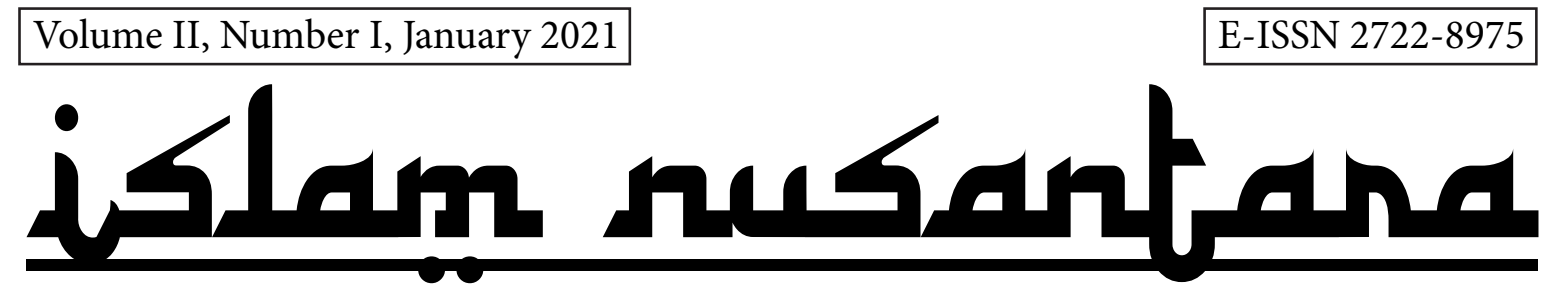

Journal for the Study of 7slamic History and Culture

Exploring the Reality and Aspirations of Muslims

The divisions of the Umat in Indonesia

Hisanori Kato

Defending Islam Nusantara at the Frontline

Experiment to shape moderatism among Non-structural

Nahdliyyin Community

Hamdani

Bahasa dan Kekuasaan dalam Historiografi Islam

Marshall G.S. Hodgson

Greg Soetomo

Keberagaman Semu dan Dilema Minoritas

di Kota Banda Aceh

Teuku Kemal Fasya

$$
\begin{aligned}
& \text { الشيخ مختار بن عطارد البوغوري الجاوي ثُ المكي ( } 1930 \text { - } 1862
\end{aligned}
$$

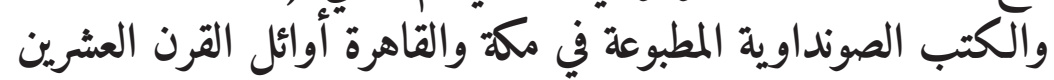

$$
\begin{aligned}
& \text { Ginanjar Sya'ban }
\end{aligned}
$$

Book Review

Jawa, Islam dan Nusantara:

Memposisikan Agama dalam Keragaman Budaya

Riwanto Tirto Sudarmo 


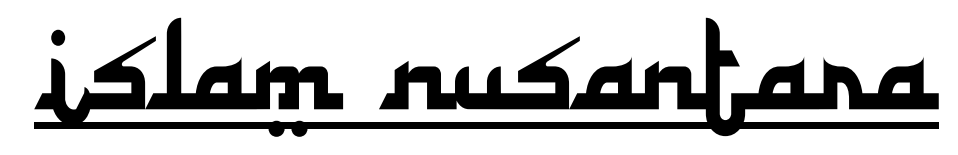

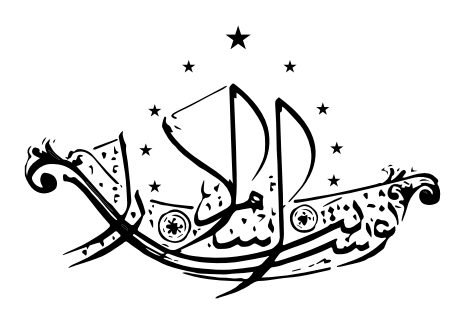




\section{Author Guideline}

I

slam Nusantara Journal for the Study of Islamic History and Culture facilitates publication of article and book review on study of Islam, Muslim culture, social and politics in Southeast Asia (Nusantara) and beyond. It is published twice a year and written in Indonesia, English and Arabic. It aims to present academic insight of social and cultural complexity of Muslim world in Southeast Asia under the frame of dialectic between Islam and local culture or cultural realities.

The journal invites scholars and experts working in various disciplines in the Islamic studies, humanities and social sciences. Articles should be original, research-based, unpublished and not under review for possible publication in other journals. All submitted papers are subject to review of the editors, editorial board, and blind reviewers.

Papers submitted for publication must conform to the following guidelines:

1. Papers must be typed in one-half spaced on A4-paper size;

2. Papers' length is about $8,000-10,000$ words;

3. All submission must include a 200-300 word abstract;

4. Full name(s) of the author(s) must be stated, along with his/her/their institution and complete e-mail address;

5. All submission should be in Microsoft Word, RTF, or WordPerfect document file format;

6. Arabic words should be transliterated according to the style of 'Islam Nusantara Studies';

7. Bibliographical reference must be noted in footnote and bibliography according to 'Islam Nusantara Studies' style.ain. 


\section{Examples of footnote style:}

${ }^{1}$ Ryan Sugiarto, Psikologi Raos: Saintifikasi Kawruh Jiwa Ki Ageng Suryomentaram, (Yogyakarta: Pustaka Ifada, 2015), p. 139.

${ }^{2}$ Nur Syam, Tarekat Petani: Fenomena Tarekat Syattariyah Lokal, (Yogyakarta: LkiS, 2013), p. 164.

${ }^{3}$ Syam, Tarekat Petani, p. 173.

${ }^{4}$ Ubaidillah Achmad dan Yuliyatun Tajuddin, Suluk Kiai Cebolek Dalam Konflik Keberagamaan dan Kearifan Lokal, (Jakarta: Prenada, 2014), p. 140.

${ }^{5}$ Nur Syam, Tarekat Petani, p. 99.

${ }^{6}$ M. Quraish Shihab, Tafsir Al-Misbah, vol. 14 (Bandung: Lentera Hati, 2013), p. 167.

${ }^{7}$ Deny Hamdani, "Cultural System of Cirebonese People: Tradition of Maulidan in the Kanoman Kraton," Indonesian Journal of Social Sciences 4, no. 1 (January-June 2012): p.12.

${ }^{8}$ Hamdani, "Cultural System of Cirebonese People," p. 14.

${ }^{9}$ Deny Hamdani, “Raison de’etre of Islam Nusantara," The Jakarta Post, 06 Agustus 2015, p. 5.

${ }^{10}$ Azyumardi Azra, "Islam di "Negeri Bawah Angin" dalam Masa Perdagangan," Studia Islamika 3, no. 2 (1996): h. 191-221, review buku Anthony Reid, Southeast Asia in the Age of Commerce (New Haven: Yale University Press, 1988).

\section{Example of Bibliography}

Suaedy, Ahmad. Gus Dur, Islam Nusantara dan Kewarganegaraan Bineka: Penyelesaian Konflik Aceh dan Papua 1999-2001. Jakarta: Gramedia, 2018.

Madjid, M. Dien dan Wahyudi, Johan. Ilmu Sejarah: Sebuah Pengantar. Jakarta: Prenada Media Group, 2014.

Banawiratma, JB. dkk., Dialog Antarumat Beragama: Gagasan dan Praktik di Indonesia. Bandung: Mizan Media Utama, 2010.

Sejarah Melayu/Malay Annals. Kuala Lumpur, Oxford University Press, 1970.

Tim Forza Pesantren. Ijtihad Politik Islam Nusantara:Membumikan Fiqih Siyasah Melalui Pendekatan Maqasid asy-Syariah. Kediri, Lirboyo Press, 2015.

Mastuki dan El-Saha, M. Ishom, ed. Intelektualisme Pesantren: Potret Tokoh dan Cakrawala Pemikiran di Era Pertumbuhan Pesantren. Jakarta: Diva Pustaka, 2003.

Suriasumantri, Jujun S. Ilmu Dalam Perspektif: Sebuah Kumpulan Karangan Tentang Hakekat Ilmu, Cet. XII. Jakarta: Yayasan Pustaka Obor Indonesia, 2012. 
Simuh. Sufisme Jawa: transformasi tasawuf Islam ke mistik Jawa. Yogyakarta: Yayasan Bentang Budaya, 1995. Reprint, Yogyakarta: Narasi, 2016.

Muhajir, Afifuddin, "Islam Nusantara untuk Peradaban Indonesia dan Dunia." Dalam Akhmad Sahal dan Munawir Aziz, ed. Islam Nusantara: Dari Ushul Fiqh Hingga Konsep Historis. Bandung: Mizan Pustaka, 2015.

Islam, Adib Misbahul. "Nazam Tarekat: Perlawanan Kiai Ahmad ar-Rifa’i terhadap Birokrasi." Dalam Islam Nusantara Past and Present:Proceeding of International Conference on Islam Nusantara (ICON) 2014. Jakarta: Pusmabit, 2014: h. 55-73.

Affan, Heyder. "Polemik di balik istilah 'Islam Nusantara." Artikel diakses pada 22 Juni 2015 dari http://www.bbc.com/indonesia/berita_indonesia/2015/06/150614_indonesia_ islam_nusantara

Malikov, Azim. "Islam: Saints and Sacred Geographies." Dalam Suad Joseph, ed. Encyclopedia of Women and Islamic Cultures, vol. V. Leiden: Brill, 2007: h. 223-225.

Hamdani, Deny. "Raison deetre of Islam Nusantara." The Jakarta Post, 06 Agustus 2015.

“Batunaga, Bagian dari situs lebih luas," Pikiran Rakyat, 16 Mei 2014.

Hamdani, Deny. "Cultural System of Cirebonese People: Tradition of Maulidan in the Kanoman Kraton." Indonesian Journal of Social Sciences 4, no. 1 (January-June 2012): h.12.

Hosen, Nadirsyah. "Islam Nusantara: Islam Lokal yang Menuju Islam Global?" Gatra, 2 Maret 2016, h. 60.

El-Mawa, Mahrus. "Syattariyah wa Muhammadiyah: Suntingan Teks, Terjemahan dan Analisis Karakteristik Syatariyah di Keraton Kaprabonan Cirebon Pada Akhir Abad ke-19.” Disertasi S3 Fakultas Ilmu Pengetahuan Budaya, Universitas Indonesia, 2015.

Azra, Azyumardi. "Islam di "Negeri Bawah Angin" dalam Masa Perdagangan." Studia Islamika 3, no. 2 (1996): h. 191-221. Review buku Anthony Reid, Southeast Asia in the Age of Commerce. New Haven: Yale University Press, 1988.

Taimiyya, Ibnu. Minhaj as-Sunnah an-Nabawiy. T.tp.: Darul Urubiyya, 1962.

Dawud, Abu. Sunan. Kairo: T.pn., 1951.

Bajuri, Ibrahim. Hasyiah al-Bajuri 'ala Matn al-Burdah. Bandung: Darul Ma’arif, t.t. 


\section{Guidelines for Book Reviews}

1. Please include, at the beginning of the review:

Author, Title, Place, Publisher, Date, number of pages, ISBN E.g., Turabian, Kate L. A Manual for Writers of Term Papers, Theses, and Dissertations. Sixth edition. Chicago and London: University of Chicago Press, 1996. $308+$ ix pp. ISBN: 0-226-81627-3.

2. The review should begin with a brief overall description of the book.

3. Matters that may be considered in the body of the review include:

The strengths and weaknesses of the book.

Comments on the author's style and presentation.

Whether or not the author's aims have been met.

Errors (typographical or other) and usefulness of indices.

Who would the book be useful to?

Would you recommend it for purchase?

4. The average review should be about 3000 words long. The name, affiliation and email address of the reviewer should appear at the end of the review.

5. The preferred format for submissions is MS-Word. 


\section{islam nusantane \\ Journal for the Study of Islamic History and Culture}

Volume II, Number I, January 2021

\section{EDITOR-IN-CHIEF}

Ahmad Suaedy, (Scopus ID: 56419869500) Faculty of Islam Nusantara UNUSIA, Jakarta

\section{MANAGING EDITOR}

Ngatawi El-Zastrow, Faculty of Islam Nusantara UNUSIA, Jakarta

\section{INTERNATIONAL EDITORIAL BOARD}

Said Aqil Siradj, Faculty of Islam Nusantara UNUSIA, Jakarta

Robert W. Hefner, (Scopus ID: 36856758800) Boston University, Boston USA

Okamoto Masaaki, (Scopus ID: 57191206120), Kyoto University, Kyoto Japan

Dien Madjid, State Islamic University Syarif Hidayatullah Jakarta, Jakarta

Endang Turmudzi, Indonesian Institute of Sciences (LIPI)

Alwi A. Shihab, Indonesian Muslim Intellectual and expert on Middle East Studies and Muslim Civilization James Bourk Hoesterey, Emory University, Atlanta GA, USA

Hisanori Kato, (Scopus ID: 55996362300), Chuo University, Tokyo Japan

Abdul Moqsith, State Islamic University Syarif Hidayatullah Jakarta, Jakarta

Sahiron Syamsuddin, (Scopus ID: 55996362300) State Islamic University Sunan Kalijaga, Yogyakarta

Muhammad Ishom, State Islamic University Sultan Maulana Hasanuddin, Banten

Azhar Ibrahim, (Scopus ID: 7202979037) National University of Singapore, Singapore

ADVISORY EDITORS:

Hamdani, (Scopus ID: 57200648495) Faculty of Islam Nusantara UNUSIA, Jakarta

\section{EDITORIAL BOARD:}

Maria Ulfah, Faculty of Islam Nusantara UNUSIA, Jakarta

Ulil Abshar Abdalla, Faculty of Islam Nusantara UNUSIA, Jakarta

Syamsul Hadi, Faculty of Islam Nusantara UNUSIA, Jakarta

Ali Abdillah, Faculty of Islam Nusantara UNUSIA, Jakarta

Ayatullah, Faculty of Islam Nusantara UNUSIA, Jakarta

Ulil Abshar, State Islamic University Syarif Hidayatullah, Jakarta

Ahmad Ginandjar Sya'ban, Faculty of Islam Nusantara UNUSIA, Jakarta

Idris Masudi, Faculty of Islam Nusantara UNUSIA, Jakarta 


\section{PEER REVIEWERS}

James Bourk Hoesterey, Emory University, Atlanta GA, USA

Hisanori Kato, (Scopus ID: 55996362300), Chuo University, Tokyo Japan

A Gaffar karim, Gadjah Mada University, Yogyakarta

Tri Chandra Arifianto, University of Jember, Jember

Jajang Jahroni, State Islamic University Syarif Hidayatullah, Jakarta

Yunus Masrukhin, State Islamic University Sunan Kalijaga, Yogyakarta

Faried F. Saenong, Victoria University of Wellington, Wellington, New Zealand

Merry Kolimon, Artha Wacana Christian University, Kupang

Falikul Isbah, Gadjah Mada University, Yogyakarta

Zacky K. Umam, Abdurrahman Wahid Centre, University of Indonesia, Depok

Arif Zamhari, State Islamic University Syarif Hidayatullah, Jakarta

Amri Marzali, University of Indonesia, Depok

ISLAM NUSANTARA: Journal for the Study of Islamic History and Culture facilitates the publication of article and book review on study of Islam, Muslim culture, social, politics and history in Southeast Asia (Nusantara) and beyond. It is published twice a year and written in Indonesia, English and Arabic. It aims to present academic insight of social and cultural complexity of Muslim world in Southeast Asia under the frame of dialectic between Islam and local culture or cultural realities.

The journal invites scholars and experts working in various disciplines in Islamic studies, humanities, and social sciences. Articles should be original, researchbased, unpublished and not under review for possible publication in other journals. All submitted papers are subject to a review of the editors, editorial board, and blind reviewers.

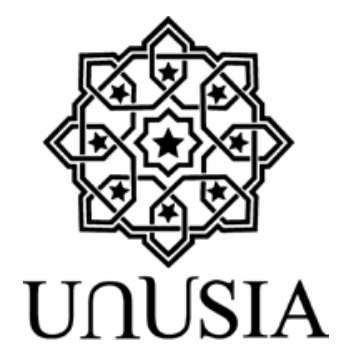

EDITORIAL JOURNAL

Gedung Kampus UNUSIA Lantai 2

Jl. Taman Amir Hamzah No. 5 Jakarta Pusat 10430

E-mail: Islamnusantarajournal@unusia.ac.id or Journalofislamnusantara@gmail.com

Website : http://journal.unusia.ac.id/index.php/

ISLAMNUSANTARA/about 


\section{Table of Contents}

Articles

1

Exploring the Reality and Aspirations of Muslims

The divisions of the Umat in Indonesia

21 Hamdani

Defending Islam Nusantara at the Frontline

Experiment to shape moderatism among Non-structural

Nahdliyyin Community

41 Greg Soetomo

Bahasa dan Kekuasaan dalam Historiografi Islam

Marshall G.S. Hodgson

71 Teuku Kemal Fasya

Keberagaman Semu dan Dilema Minoritas di

Kota Banda Aceh

93 Ginanjar Sya’ban

$$
\begin{aligned}
& \text { الشيخ مختار بن عطارد البوغوري الجاوي ثم المأكي ( } 1930 \text { - } 1862
\end{aligned}
$$

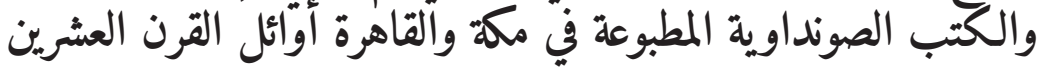

Book Review

113 Riwanto Tirto Sudarmo

Jawa, Islam dan Nusantara:

Memposisikan Agama dalam Keragaman Budaya 
Teuku Kemal Fasya

\title{
Keberagaman Semu dan Dilema Minoritas di Kota Banda Aceh
}

Universitas Malikussaleh

kemalfasya@unimal.ac.id

\begin{abstract}
7 his study examines the understanding of the concept of diversity (pluralism and multiculturalism) in the city of Banda Aceh; the capital city of Aceh Province which is now more than 800 years old. Can the city be classified as a diversity-friendly city as it is embedded for Pematang Siantar, Manado, Kupang, or Bali, which are among the most diversity friendly regions and are tolerant to other religions and beliefs? This study adopts socio-qualitative with an ethnographic approach to present arguments about the diversity in the city of Banda Aceh. The analytical instrument seeks to empathize with Banda Aceh's value of inductivity, as well as its "particularistic" dimension so that it can be understood emphatically. This article seeks to test the hypothesis of whether or not Banda Aceh City government has sufficiently promoted the culture of minority groups, not only protecting them from violence and granting the right to live and do business. By using observation and in-depth interview techniques, this paper also shows the enigmatic side of minority groups, including the exclusion of "subaltern" groups: the weakest minority and can be called the minority of the minorities. The most apparant of this minority group is the Chinese gets a wider portion of the discussion, compared to other minorities. This is because of the complexity that this community enjoys which shapes their lives with other minority groups and builds the concept of encounters with local communities in Banda Aceh. The diversity values of this city experienced a dynamic change. In the last fifteen years, the diversity was best promoted in the city of Banda Aceh during the governance period of Mawardy Nurdin who served as mayor of Banda Aceh from 2007-2014.
\end{abstract}

Key words: diversity village, ethnic Chinese, minority, ethnography 


\section{Abstrak}

Artikel ini menginvestigasi pemahaman konsep keragaman (pluralisme dan multikulturalisme) di kota Banda Aceh, ibu kota Provinsi Aceh yang sekarang berusia lebih dari 800 tahun. Dapatkah sebuah kota diklasifikasikan sebagai kota yang ramah keragaman sebagaimana diberlakukan bagi kota Pematang Siantar, Manado, Kupang atau Bali, manakah diantara daerah-daerah tersebut yang paling ramah terhadap keragaman dan toleransi terhadap terhadap agama dan kepercayaan yang lain? Studi ini menggunakan metode kualitatif sosial dengan pendekatan etnografis untuk menghadirkan argumen tentang keragaman di kota Banda Aceh. Instrumen analitis digunakan untuk berempati dengan nilai induktivitas kota Banda Aceh, juga dimensi "partikularistiknya" sehingga dapat dipahami secara empatik. Artikel ini berusaha menguji hipotesis apakah pemerintahan kota Banda Aceh telah mempromosikan budaya kelompok minoritas, tidak hanya melindungi mereka dari kekerasan dan memberi hak untuk hidup dan berusaha? Dengan teknik observasi dan interview mendalam dalam mengumpulkan data primer, paper ini juga menunjukkan sisi enigmatik dari kelompok-kelompok minoritas, termasuk eksklusi kelompok-kelompok "subaltern": kelompok minoritas terlemah dan dapat disebut sebagai minoritas dari sejumlah minoritas yang ada. Dinamika minoritas yang paling mengemuka yaitu kelompok etnis China mendapatkan porsi pembahasan yang lebih luas dibandingkan dengan minoritas yang lain. Ini dikarenakan adanya kerumitan bahwa komunitas ini menikmati, karena kaitan agama dan etnis, yang membentuk kehidupan mereka dengan kelompok minoritas yang lain juga membangun konsep perjumpaan dengan komunitas lokal di Banda Aceh. Nilai-nilai keragaman kota ini mengalami situasi pasang surut. Dalam kurun waktu 15 tahun terakhir, keragaman paling banyak dipromosikan di kota Banda Aceh selama pemerintahan Mawardy Nurdin yang menjabat Walikota Banda Aceh tahun 2007-2014.

Kata kunci: keragaman, etnis China, minoritas, etnografi

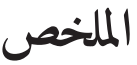

سيقوم هذا البحث بالدراسة الميدانية التحليلية على فهم فكرة التعددية الثقافية في مدينة باندا أتشيه6

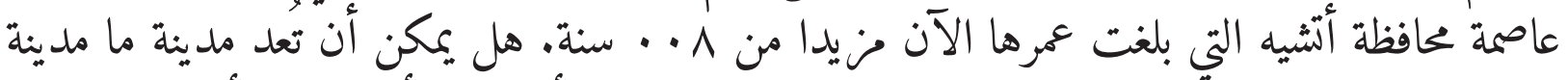

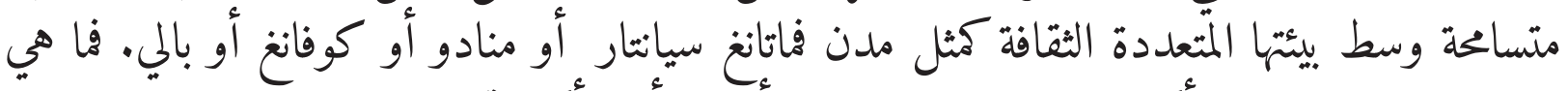

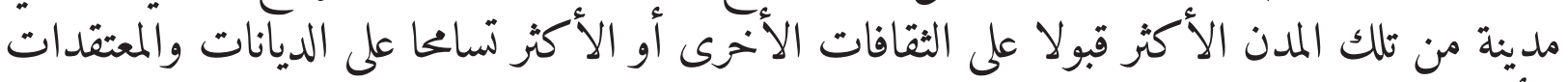

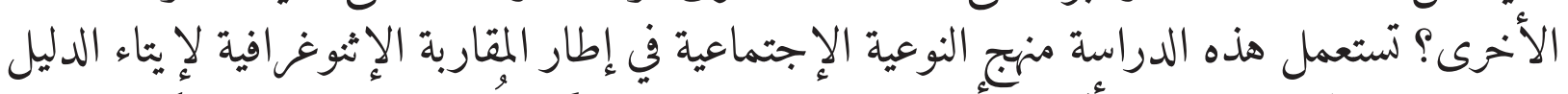

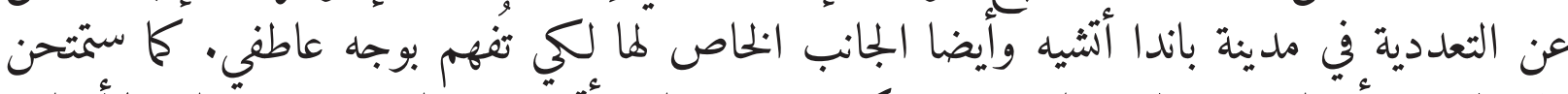

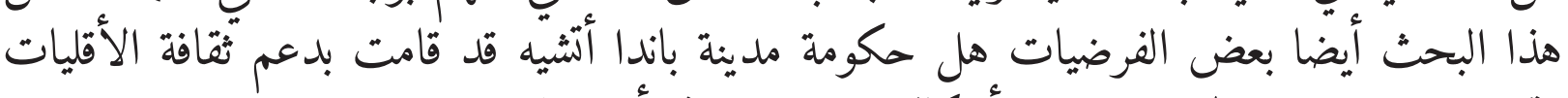
وتشجيعها، ليست فقط همايتها عن أشكال العنف الثقافي أو اعطائها حقوق الحياة والعمل ب فبتقنية

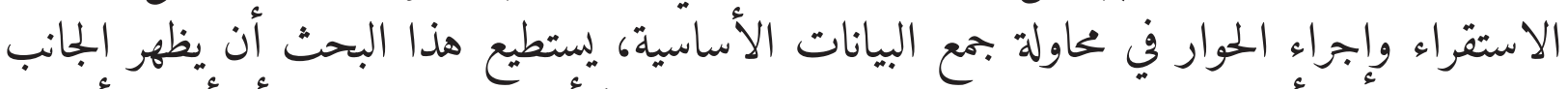

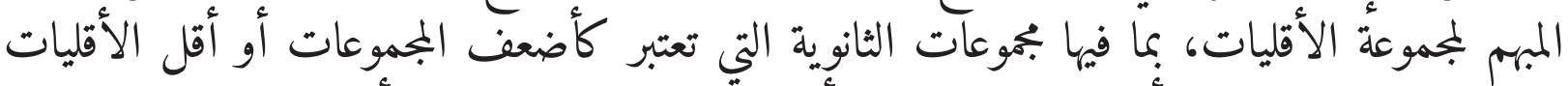

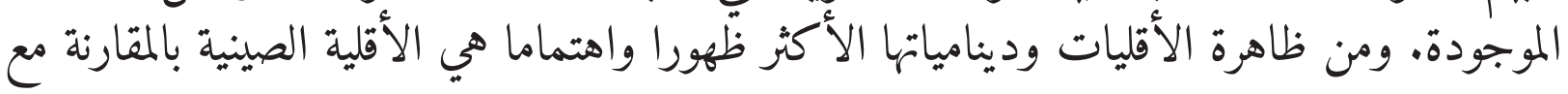




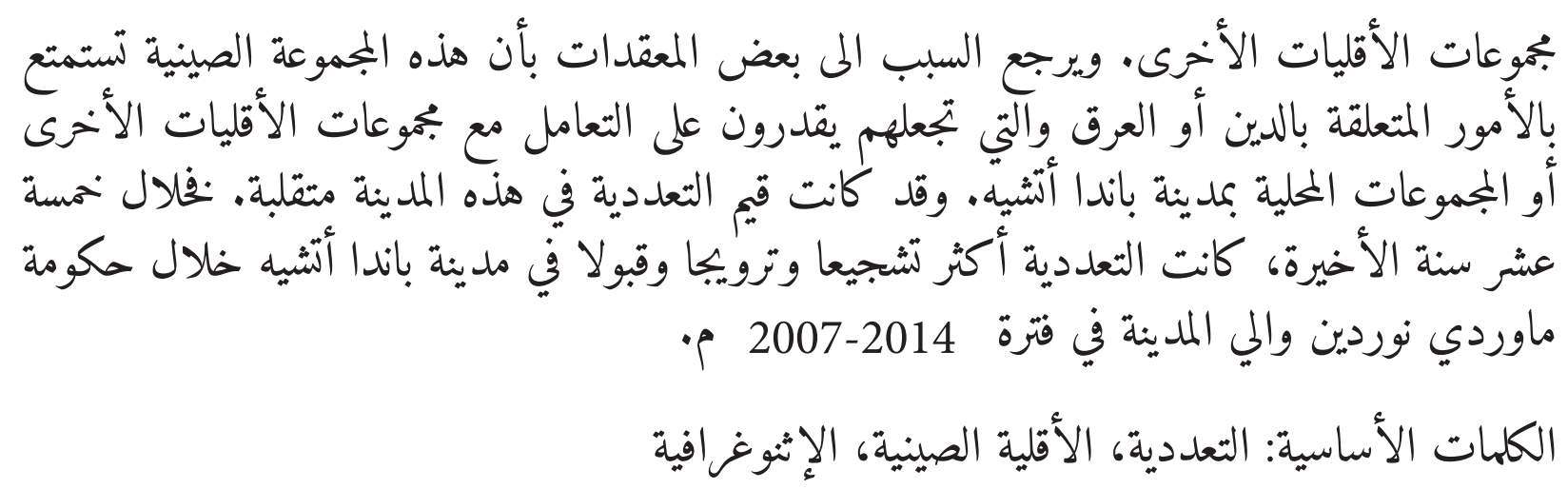

\section{Pendahuluan}

Tulisan ini pengembangan hasil riset yang pernah penulis lakukan di Banda Aceh yang bertema genealogi keberagaman pada 2016. Saat itu riset ini dilaksanakan melalui kerja sama dengan Lakpesdam NU Aceh. Lakpesdam NU dan Yayasan Hakka Aceh saat itu melaksanakan program inklusi sosial untuk "kampung-kampung keberagaman" di tempat yang pernah menjadi ibukota Kerajaan Aceh Darussalam dan tahun ini berumur 815 tahun. ${ }^{1}$ Ringkasan hasil penelitian ini pernah diterbitkan di Harian Kompas pada 31 Desember 2016. Namun demikian laporan riset secara keseluruhan belum pernah diterbitkan di dalam jurnal atau buku mana pun. ${ }^{2}$

Fakta arkeologis dan sejarah menunjukkan bahwa Banda Aceh bisa disebut sebagai salah satu kota tertua di Nusantara. Ia bisa disandingkan dengan Kota Palembang (1337 tahun), Salatiga (1250 tahun), Magelang (1115 tahun), atau Kediri (806 tahun). ${ }^{3}$ Sejarah panjang kota Banda Aceh telah diisi dengan pelbagai dinamika, salah satunya ialah perjumpaan dan kerja sama dengan masyarakat non-Aceh, yaitu dengan etnis-etnis dari Tiongkok, India, dan Eropa selama ratusan tahun.

Namun di era modern, Banda Aceh sempat dianggap sebagai salah satu kota yang tidak toleran di Indonesia. Dari survei Setara Institute pada 2018, Banda Aceh menempati posisi kedua sebagai kota tidak toleran di Indonesia setelah DKI Jakarta. ${ }^{4}$ Bahkan Banda Aceh sempat bertengger di tiga besar selama beberapa tahun sebagai kota tidak toleran sehingga melahirkan reaksi keras dari kelompok elite kota. ${ }^{5}$

1 Data resmi tentang sejarah kelahiran kota Banda Aceh terdapat juga di situs Pemerintahan Kota Banda Aceh. Bukti itu berdasarkan penelitian arkeologis pada batu nisan Sultan Firmansyah, cucu Sultan Johansyah di Kampung Pande, bahwa Kota Banda Aceh yang menjadi ibukota Kerajaan Aceh Darussalam didirikan pada 22 April 1205 atau 1 Ramadhan 601 H. Kerajaan Aceh Darussalam dibangun di atas puing-puing kerajaan-kerajaan Hindu dan Budha seperti Kerajaan Indra Purba, Kerajaan Indra Purwa, Kerajaan Indra Patra dan Kerajaan Indra Pura. http://www.bandaacehkota.go.id/p/sejarah.html

2 Teuku Kemal Fasya, “Keberagaman”, Kompas, 31 Desember 2016.

3 Hipwee, "10 Kota dengan Usia Paling Tua di Indonesia. Ada yang Sudah Ratusan Bahkan Ribuan Tahun!”, 9 Oktober 2018. Diakses dari https://www.hipwee.com/travel/10-kota-dengan-usia-paling-tua-di-indonesia-adayang-sudah-ratusan-bahkan-ribuan-tahun/

4 Setara, "SETARA Institute: Singkawang, Kota Paling Toleran Se-Indonesia", 7 Desember 2018. Diakses dari https://setara-institute.org/setara-institute-singkawang-kota-paling-toleran-se-indonesia/

$5 \quad$ Walikota Aminullah protes keras dengan dimasukkannnya Banda Aceh sebagai kota tidak toleran di Indonesia, setelah sebelumnya pada survei 2015 Banda Aceh menempati urutan ketiga dan pada 2017 "naik" menjadi urutan kedua sebagai kota intoleran. Detik.com, "Protes Keras Banda Aceh 3 Kali Masuk Kota Tidak Toleran”, 12 Desember 2018. Diakses dari https://news.detik.com/berita/d-4339550/protes-keras-banda-aceh-3-kalimasuk-kategori-kota-tidak-toleran 
Secara historis Banda Aceh memiliki sejarah pembauran dan keberagaman yang cukup unik. Pada masa kolonial, kota ini sempat dinamakan Kutaraja. Namun kemudian nama Banda Aceh kembali dipakai setelah 89 tahun pada 9 Mei 1963 berdasarkan Keputusan Menteri Pemerintahan Umum dan Otonomi Daerah No. Des 52/1/43-43. Perubahan nama itu tidak membawa pengaruh pada aspek keberagaman Kota Banda Aceh. ${ }^{6}$

Warisan keberagaman itu sedikit banyak masih terlihat sampai sekarang dan menarik ditelisik secara etnografis. Kota ini telah terbiasa melakukan perjumpaan kultural khas urban, yaitu antara masyarakat asli, keturunan, dan diaspora. Saling-silang perjumpaan antara masyarakat muslim dan nonmuslim juga ditandai dengan keberadaan vihara, kuil, dan gereja di samping mesjid-mesjid tua. Demikian juga perkampungan non-muslim juga terdapat di beberapa sudut Kota Banda Aceh, meskipun ada kampung yang kini telah hilang. ${ }^{7}$

Setelah reformasi 1998 dan terjadi perubahan politik mendasar di Aceh karena memasuki era konflik baru, yaitu ditandai operasi militer selama dua tahun (19 Mei 2003 - 19 Mei 2005) kemudian katastrofi tsunami (24 Desember 2004) menyebabkan kondisi Banda Aceh ikut berubah. Yang paling singnifikan ialah ketika Banda Aceh menjadi salah satu kota yang paling hancur akibat tsunami, dan kemudian menjadi ibukota "bencana dunia". Ratusan triliun rupiah anggaran dan ratusan lembaga donor dunia dan LSM asing dan nasional bermukim di Banda Aceh. Keberadaan mereka bukan semata memberikan bantuan kemanusiaan tapi juga pada beberapa aspek terjadi kolonialisasi budaya dan mengubah lanskap kota melalui proyek rehabilitasi dan rekonstruksi. ${ }^{8}$

Demikian pula kesepakatan damai antara pihak Gerakan Aceh Merdeka (GAM) dan Pemerintah Indonesia pada 15 Agustus 2005 hingga hadirnya undang-undang otonomi

6 http://www.bandaacehkota.go.id/p/sejarah.html. Namun di kalangan sejarawan masih bersilang pendapat tentang nama Koetaradja, apakah benar pemberian kolonial Belanda atau nama itu memang pilihan penguasa Aceh saat itu, yang juga berdekatan sejarahnya dengan aneksasi kolonial Belanda pada 26 Maret 1973. Pengubahan nama Banda Aceh menjadi Kutaraja terjadi pada 1874, di tengah perang gerilya yang dilakukan oleh pejuang Aceh. Wawancara dengan Teuku Rizasyah Mahmudi, aktivis Masyarakat Peduli Sejarah (Mapesa) Aceh, 26 Februari 2016. Bandingkan dengan penelusuran sejarah yang dilakukan Anthony Reid (1987), bahwa nama Banda Aceh dan Kutaraja masih sering dipertukarkan dan digunakan hingga perlawanan itu berhenti pada 1913, atau 40 tahun setelah berperang tanpa henti. Sebelum 1913, nama Kutaraja dan Banda Aceh masih digunakan, baik oleh pihak kolonial dan elite pejuang Aceh. Setelah 1914, penguasa Belanda telah berhasil menguasai sistem politik dan administratif bagi wilayah Aceh, termasuk Banda Aceh, sehingga penggunaan nama Kutaraja lebih digunakan, termasuk dalam memungut pajak dari masyarakat. Baca Reid, Perjuangan Rakyat : Revolusi dan Hancurnya Kerajaan Sumatera (Jakarta : Pustaka Sinar Harapan, 1987), h. 31-34.

7 Seorang budayawan, wartawan senior, dan kolektor benda-benda kuno Aceh, H. Harun Kechiek Leumiek, mendokumentasikan dalam sebuah bukunya (2008), tentang jejak-jejak multikulturalisme Banda Aceh. Buku itu semacam politik ingatan bagi masyarakat Aceh untuk mengingat jejak-jejak etnografis, sejarah, dan budaya Kota Banda Aceh yang sebagian telah hilang dan berubah struktur kota karena tsunami, tapi sebagian lainnya menjadi hilang karena politik rekonstruksi yang tidak ramah pada aspek budaya dan itu telah berlangsung bahkan sebelum tsunami. Salah satunya adalah telah hilangnya Kampung Sentosa, yang dulunya adalah perkampungan India (Kampung Keling), yang menempati situs cagar budaya, Gunongan atau pemandian bagi Putro Phang, istri dari Sultan Iskandar Muda. Demikian pula keberadaan Simpang Jambo Tape di masa lalu juga dikenal sebagai "lapak tuak", yang diperuntukkan bagi para pengunjung Kota Banda Aceh yang non-muslim dan menginginkan minuman alkohol. Harun Kechiek Leumik baru meninggal dunia pada 16 September 2020. Baca H. Harun Keuchiek Leumiek, Potret Sejarah Banda Aceh (Banda Aceh : Toko Mas dan Souvenir H. Harun Kechiek Leumiek, April 2008).

8 Penulis pernah memotret kerusakan kota akibat pembangunan tanpa mengindahkan aspek perlindungan kebudayaan melalui sebuah artikel. Teuku Kemal Fasya, "Bersama Bantuan Aceh Masih Menderita”, Kompas, 24 Desember 2005. 
khusus baru yaitu UU No. 11/2006 sejak 11 Juli 2006 telah ikut memberikan andil pada pembentukan politik identitas baru di Aceh termasuk di Banda Aceh sebagai ibukota provinsi. Konfigurafi keberagaman ikut memengaruhi politik dan kebijakan apalagi sejak pemberlakuan qanun-qanun Syariat Islam dan peneguhan Banda Aceh sebagai Kota Madani.

Kata "madani" yang disematkan ke Banda Aceh ini sayangnya tidak berangkat dari aktualisasi nilai normatif dalam sejarah Islam. Konseptualisasi tidak mengacu pada nilainilai dan peradaban tinggi, tapi pemahaman subjektif untuk menyembunyikan kelemahan tata pemerintahan dan tata laku kebudayaan dan akhlakul karimah di kota ini. Buktinya kualitas islami Banda Aceh hanya berada pada posisi ke-19 menurut survei Maarif Institute pada 2017. ${ }^{9}$ Interpretasi pelaksanaan Syariat Islam dan praktiknya kadang mendiskreditkan posisi kelompok minoritas non-muslim, sehingga dipertanyakan apakah kota ini cukup memadai disebut sebagai kota penganjur pluralisme dan multikulturalisme.

Masalah yang digali dalam penelitian ini melihat fenomena ke

beragaman di Banda Aceh, apakah benar-benar merepresentasikan semangat multikulturalisme yang ideal, atau hanya sebuah realitas semu ketika posisi kelompok minoritas hanya sebagai "penonton jauh" dan terpingirkan dari akses publik dan politik inklusi sosial? Hal ini penting dan menjadi tantangan bagi kota yang dianggap sebagai simbol Provinsi Aceh yang dikenal sebagai salah satu daerah yang melaksanakan kebijakan Syariat Islam di Indonesia.

\section{Metode Penelitian}

Tulisan ini menggunakan metode penelitian sosial-kualitatif dengan pendekatan etnografi. Pendekatan etnografi bertujuan memberikan perhatian pada aspek induktivitas dan pentingnya kasus lokal dilihat secara mendalam. Pendekatan etnografi menolak melakukan deduktivikasi atau komparasi terlalu meluas, sehingga mengaburkan pentingnya melihat masalah sebagai studi kasus otonom.

Pendekatan etnografis digunakan untuk melihat aspek-aspek kultural, bersifat khusus, empiris, dan induktif. Gaya etnografis untuk menggeledah masalah identitas lainnya seperti agama dan etnis mencari hal yang semakin populer dalam penulisan sejarah tempat dan masyarakat. Menurut Karen O’Reilly, profesor sosiologi dari Loughborough University, Inggris, penelitian etnografi tidak mudah diterjemahkan atau diklaim sebagai milik satu rumpun ilmu, karena digunakan melalui pelbagai cara, disipilin pengetahuan (bukan hanya antropologi), dan beragam tradisi penelitiannya. ${ }^{10}$

Secara umum etnografi adalah analisis penelitian yang beranjak dari investasi "sejumlah orang" untuk memahami sebuah masyarakat dalam durasi pengamatan tertentu. Dalam konteks penelitian ini, tujuannya adalah memahami akar pemahaman masyarakat atas dunia yang mereka hadapi sehari-hari melalui situasi kontemporer dan dilihat secara induktif. Pengertian induktif adalah memperhatikan komentar, deskripsi, dan "suara tunggal" dari sejarah masyarakat atau lokasi secara khusus. ${ }^{11}$ Bahkan dalam penelitian

9 Ahmad Zaky, “Madanikah Banda Aceh?”, acehinstitute.org, 2 Juni 2017.

10 Karen O’Reilly, Ethnographic Methods (Oxon : Routledge, 2005), h. 1.

11 O'Really, h. 22. 
etnografi, kutipan langsung yang khas dari informan sengaja ditampilkan untuk membantu pembaca mendapatkan konstruksi kebudayaan sebuah masyarakat.

Teknik penelitian lapangan dilakukan dengan dua cara, yaitu observasi dan wawancara mendalam, termasuk mengamati gestur informan yang diwawancarai. Hal itu bisa memberikan "teks" yang penuh nuansa untuk menyelami kehidupan mereka yang lebih luas. Dalam konteks penggalian data lapangan, sebenarnya etnografi banyak mengambil sumbangan dari ranah antropologi, yaitu peneliti terlibat dalam perbincangan informal dengan informan melalui kegiatan harian. Seperti dikatakan perintis penelitian lapangan etnografi modern, Bronislaw Malinowski, para etnografer akan bisa juga meramalkan masalah-masalah (foreshadowed problems) masyarakat yang diteliti, karena kemampuan eksplorasinya di lapangan. ${ }^{12}$

Secara empiris, penelitian sosial etnografi digunakan sebagai instrumen kontestasi atas pendekatan statistik dan "borjuis" ala riset pemerintah, yang melihat ukuran keberhasilan dan fakta pembangunan hanya berdasarkan pendekatan statistik dan studi "di atas meja" (desk review). Pendekatan etnografi ini mencoba mengangkat pengetahuan dari sisi informan untuk melihat struktur sosial secara lebih luas dan merelativisasi "efek sensus" akibat pendekatan top down ala penguasa. ${ }^{13}$ Makanya dengan pendekatan etnografis bisa tergambarkan kondisi keberagaman Banda Aceh dari mata kelompok non-pemerintah sebagai subjek utama. Adapun pandangan dari elite pemerintah ditempatkan sebagai subjek kedua atau dinilai secara etik.

Para informan yang menjadi sumber utama narasi penelitian ini adalah kaum minoritas, baik secara agama dan etnis, yang memiliki kisah biografis dan identitas diri berbedabeda. ${ }^{14}$ Pengambilan kesimpulan atas narasi-narasi itu diperlakukan secara kasuistik dan harus ditempatkan berdasarkan kategori latar-belakang dan historis-personal masingmasing.

Adapun untuk merekonstruksi sejarah kelompok minoritas, sebagian digunakan pendekatan sejarah tutur (oral history). Penggunaan sejarah tutur ini dilakukan karena minimnya dokumen sejarah yang bisa melihat sejarah minoritas secara adil dan empatik. Kebanyakan ingatan tentang masa lalu nenek moyang komunitas minoritas, apalagi dengan kesadaran disiplin sejarah yang minim, tersapu oleh narasi mayoritas atau narasi elite politik. Pendekatan oral history mampu menangkal narasi sejarah politis dari cara pandang elite mayoritas. ${ }^{15}$ Pendekatan sejarah tutur untuk minoritas di Kota Banda Aceh menjadi tepat dan signifikan.

\section{Eksistensi "Kampoeng Tjina"}

Salah satu etnis minoritas terbesar di Banda Aceh dan cukup eksis dari kegiatan ekonomi dan agama adalah Tionghoa. Masyarakat Tionghoa di Banda Aceh tinggal di beberapa

12 Paul Atkinson and Martyn Hemmersley, Ethnography: Principle in Practices Third Edition (Oxon : Taylor \& Francis E-Library, 2007), h. 3. Untuk observasi partisipatif dan wawancara mendalam telah dilakukan pada 2016 dan penulis melakukan updating data lapangan dan melakukan wawancara kepada tiga informan baru dan satu informan lama sepanjang pertengahan Oktober 2020.

13 Paul Willis, The Ethnographic Imagination (Cambridge : Polity Press, 2000), h. 34.

14 Mike Crang and Ian Cook, Doing Ethnographies (London : Sage Publication, 2007), h. 9.

15 Paul Thompson, The Voice of the Past: Oral History (Oxford: Oxford University Press, 1978), h. 28. 
kampung, dan tidak hanya terkonsentrasi kepada satu kampung. Populasi mereka saat ini hampir 5.000 jiwa. ${ }^{16}$ Kebanyakan mereka berasal dari Suku Khek (Hakka) yang bermigrasi dari Provinsi Kwantung. Etnis Tionghoa lainnya yang tinggal di Banda Aceh berasal dari suku Hok Kian, Hai Nan, dan Kong Hu. ${ }^{17}$ Etnis Hakka menjadi yang paling eksis dan memiliki organisasi yang cukup mapan di Banda Aceh, yaitu Yayasan Hakka yang terletak di Kampung Peunayong.

Meskipun pola migrasi telah berlangsung sejak abad ke-13 dan ditandai keberadaan Pecinan di Banda Aceh pada abad ke-17, ${ }^{18}$ migrasi besar-besaran terjadi pada $1875^{19}$ atau dua tahun setelah aneksasi militer Kerajaan Belanda ke Aceh pada 26 Maret 1873. Mereka didatangkan oleh Belanda dan bekerja sebagai buruh. ${ }^{20}$

Komunitas Tionghoa di Banda Aceh tinggal di beberapa kampung, tetapi yang bisa disebut sebagai Kampoeng Tjina di Banda Aceh hanya Peunayong. Peunayong berada di tengah Kota Banda Aceh, berjarak kira-kira 2 kilometer dari Mesjid Raya Banda Aceh dan 3 kilometer dari pendopo gubernur (dulunya Istana Kerajaan Aceh). Melihat dekatnya Peunayong dengan pusat "peradaban Aceh" menjadi penanda bahwa komunitas Tionghoa adalah komunitas penting bagi masyarakat Aceh.

Peunayong juga menjadi kampung yang dialiri Sungai Aceh (Krueng Aceh), urat nadi perdagangan dan pelayaran yang telah ramai sejak sebelum Kerajaan Aceh. Sungai membelah Banda Aceh sehingga kota ini terhubung oleh tiga jembatan yaitu jembatan Peunayong, jembatan Pante Pirak, dan jembatan Surabaya. ${ }^{21}$ Sedemikian sentral sejarah Peunayong ini di era modern sehingga ada tokoh publik nasional lahir di sini, di antaranya Yap Tiam Hien (25 Mei 1913-25 April 1989) pejuang HAM dan juga pendiri Peradi (Persatuan Advokat Indonesia); dan Alvin Adam (16 Juni 1971), pembawa acara dan aktor. Mereka lahir dan tumbuh di pecinan ini. ${ }^{22}$

Secara linguistik, nama Peunayong tidak berasal dari bahasa Mandarin atau subbahasa Mandarin. Kata Peunayong dan kemudian menjadi nama kampung tidak lepas dari semakin banyaknya komunitas Tionghoa berada di Banda Aceh.

Menurut Yuswar, tokoh Tionghoa Aceh yang beretnis Hok Kian, kata Peunayong terbentuk dari pola komunikasi bahasa non-verbal, yang terbentuk akibat pola komunikasi yang secara linguistik tidak dimengerti satu sama lain, antara orang Aceh dan orang Tionghoa. Ia terbentuk dari efek fonetis tentang penyebutan sesuatu.

Alkisah, pada abad 17, kapal-kapal dari Tiongkok yang datang dan mendarat di tepi Sungai Aceh disebut "kapal Jong" atau kapal-kapal pengangkut manusia dan barang. Barang-barang itu dijual di Aceh sedangkan manusia sebagian bekerja sebagai kuli di perusahaan Eropa atau kaum imigran yang melarikan diri karena konflik di Tiongkok daratan.

16 Wawancara dengan Kho Kie Siong, ketua Yayasan Hakka Aceh, 14 Oktober 2020.

17 A. Rani Usman, Etnis Cina Perantau di Aceh (Jakarta : YOI, 2009), h. 129.

18 Wawancara dengan Yuswar, tokoh Tionghoa etnis Tionghoa, wakil FKUB Provinsi Aceh dari agama Budha, 30 Januari 2016.

19 Sulaiman dkk, Perdagangan, Pengusaha Cina, Perilaku Pasar (Jakarta : Pustaka Grafika KIta, 1988), h. 22.

20 Usman, Etnis Cina, h. 4.

21 Leumik, Potret Sejarah, h. 57-63.

22 Teuku Kemal Fasya, "Minoritas dalam Strategi Multikulturalisme”, Kompas, 24 Mei 2011. 
Pola komunikasi masyarakat lokal dengan komunitas Tionghoa pendatang tidak berdasarkan bahasa pidgin atau bahasa creole. Mereka hanya mengingat nama kapalkapal yang datang itu dengan sebutan Jong. Masyarakat Aceh yang merapat di pelabuhan itu bertanya kepada komunitas Tionghoa, apakah ada kapal Jong yang datang ("Peu na Jong?)”. Dari komunikasi yang mirip bahasa non-verbal, sebutan daerah singgahan kapal itu disebut Peunayong, dan itu menjadi wilayah bermukim komunitas Tionghoa paling padat di Banda Aceh. ${ }^{23}$

Beberapa kampung lain yang memiliki populasi Tionghoa signifikan seperti Kampung Mulia, Kampung Laksana, dan Kampung Setui tidak disebut Kampung China atau China Town. Terkait Pecinan, meskipun hanya Peunayong yang sah disebut sebagai Kampoeng Tjina, ada beberapa kampung lain yang juga berpopulasi signifikan komunitas Tionghoa. Bahkan di Peunayong sendiri tidak terdapat rumah ibadah etnis Tionghoa. Tiga vihara berada di Kampung Mulia yaitu Vihara Sakyamuni, Maitri dan Dewi Samudera. Satu lagi dan merupakan vihara tertua ialah Vihara Dharma Bakti atau juga disebut Tae Pe Kong terletak di Kampung Laksana. Tae Pe Kong sendiri artinya Dewa Tanah. Hal ini mengikuti pola teologi Budha dan Kong Hu Chu yang memiliki banyak nama-nama dewa.

Kampung-kampung itu layak juga disebut sebagai Kampung Tionghoa karena populasinya. Tiga kampung yang bertetanggaan inilah (Peunayong, Laksana, dan Mulia) bisa disebut sebagai kampung keberagamaan karena komunitas Tionghoa berbaur secara akrab dengan etnis lainnya, seperti Batak, Jawa, Minang, dan tentu saja Aceh sendiri.

\section{Relasi “Mesra Tapi Curiga" Tionghoa-Aceh}

Salah satu yang membuat komunitas Tionghoa tetap berada dalam relasi "mesra-mesra curiga" dengan masyarakat Aceh karena adanya persangkaan komunitas Tionghoa memiliki sejarah kedekatan dengan Partai Komunis Indonesia (PKI) pada era Orde Lama. PKI juga berhubungan baik dengan Partai Komunis Cina (PKC) di Tiongkok. Ketika gagalnya pemberontakan PKI pada 30 September 1965, gerakan anti-Tionghoa terjadi cukup gencar termasuk di Aceh. Salah satunya terbaca dari seruan Brigadir Ishak Djuarsa, Komandan Militer Aceh, bahwa semua Tionghoa asing harus meninggalkan Aceh sebelum 17 Agustus 1966. ${ }^{24}$ Yang dimaksud asing adalah etnis Tionghoa yang tidak teregistrasi dengan sistem administrasi kependudukan Indonesia. Padahal diantara mereka banyak yang telah tinggal puluhan tahun bahkan telah menikah dan memiliki keturunan di Aceh.

Laporan di permukaan seperti terbaca di dalam buku A.Rani Usman (2009), menyebut adalah fakta pengusiran etnis Tionghoa, tetapi kejadian sebenarnya lebih mengerikan. Mereka bukan saja terusir, tapi ada di antaranya diculik pada malam hari oleh "orang tak dikenal" dan mayatnya digeletakkan begitu saja di jalan-jalan dan ruang publik di pagi hari. ${ }^{25}$ Penyebaran mayat-mayat di pagi hari adalah sebagai teror untuk simpatisan atau yang dituduh sebagai simpatisan PKI agar segera meninggalkan Banda Aceh.

Menurut Kho Kie Siong, ketua Yayasan Hakka Aceh, tuduhan orang Tionghoa

23 Wawancara dengan Yuswar.

24 A. Rani Usman, op cit., hal. 6.

25 Salah satu tempat untuk mengeksekusi etnis Tionghoa adalah lapangan Perbasi, Banda Aceh atau juga dikenal dengan Lapangan SMEP (Sekolah Menengah Ekonomi Pertama) yang merupakan tanah milik etnis Tionghoa. Lapangan ini saat ini sebagiannya berdiri SMPN 9 Banda Aceh. 
mendukung PKI tidak benar. Komunitas Tionghoa juga terbelah: ada yang mendukung organisasi PKI dan ada yang mendukung pemerintah. Klasifikasi mendukung PKI juga terlihat sumir.

Menurutnya di Banda Aceh ada dua model pengelompokan Tionghoa. Pertama, kelompok yang dianggap pro-Taiwan yaitu mereka yang menyekolahkan anak-anaknya di Chung Hua School (SMP 4 Banda Aceh saat ini). Mereka dianggap anti-komunisme. Kedua, mereka yang dituduh pendukung pro-Republik Rakyat Tiongkok (Peking) adalah yang menyekolahkan anaknya di Ching Hua School (SMA 2 Banda Aceh saat ini). Komunitas pendukung Taiwan diberi julukan pejoratif "pantat biru” (Lam Sie Fut), sedangkan yang mendukung RRT disebut "pantat merah" (Fung Sie Fut) atau pro-komunis. Pantat biru dan pantat merah itu ditandai dengan mengecat perut, bokong, atau kepala mereka dengan cat biru dan merah, termasuk juga di pintu-pintu rumah. Warna itu digunakan sebagai identitas untuk memperlakukan komunitas Tionghoa di Banda Aceh. ${ }^{26}$

Perubahan politik yang sangat radikal saat itu meninggalkan duka di kalangan etnis Tionghoa. Perlakuan negara juga sangat brutal. Baik sekolah Chung Hua yang antikomunis dan Ching Hua yang pro-komunis kedua lahan dan aset mereka dirampas oleh negara dan dijadikan sekolah negeri. Seperti juga di tempat lain di Indonesia, pada masa Orde Baru, etnis Tionghoa di Banda Aceh tidak lagi memiliki sekolah Tionghoa, sehingga sebagian besar mereka sekolah di Sekolah Kristen Methodist atau Sekolah Katolik Budi Darma. Proses pendidikan dengan sekolah afiliasi agama berbeda menyebabkan sebagian komunitas Tionghoa tidak lagi beragama leluhur (Budha), tapi beragama baru (Katolik dan Kristen). ${ }^{27}$ Beberapa di antaranya beragama Islam, tapi ketika Muslim, ia dianggap tidak lagi berada dalam radar komunitas minoritas, tapi telah dianggap sebagai bagian dari mayoritas. Meskipun tidak terjadi politik eksklusi, komunitas Tionghoa muslim sering mencari pergaulan dengan sesama Muslim Aceh. ${ }^{28}$

Politisasi masa Orde Baru ikut memengaruhi populasi Tionghoa di Banda Aceh. Sebenarnya komunitas Tionghoa sempat mengalami eksodus beberapa kali dari Aceh, yaitu 1966 pasca pemberontakan PKI 1965, konflik SARA 1981, kerusuhan menjelang kejatuhan Soeharto Mei 1998, konflik darurat militer dan sipil (2002-2005) dan tsunami 26 Desember 2005. Namun dari semua sejarah eksodus itu yang paling membekas adalah pengusiran pada 1966.

Dari laporan tahunan Kodam Iskandar Muda (edisi 1966), sepanjang awal April hingga pertengahan Agustus 1966 jumlah warga Tionghoa yang hengkang dari Banda Aceh menuju Medan berjumlah 2.146 orang. Dari jumlah itu, 1.698 orang di antaranya diberangkatkan oleh Komando Sektor Pertahanan (Kosekhan) Banda Aceh dalam beberapa tahap sebelum peringatan ulang tahun kemerdekaan Republik Indonesia 17 Agustus 1966. Sisanya, 448 orang berangkat sendiri dengan menyewa puluhan bus. Pengusiran bukan hanya terjadi di Banda Aceh, tapi dari seluruh Aceh seperti di Bireuen, Lhokseumawe, Idi Rayeuk,

26 Wawancara dengan Kho Kie Siong, 28 Januari 2016.

27 Salah satu yang berganti keyakinan ialah A Chong, sekretaris Yayasan Hakka Aceh. Ia terlahir dengan agama Budha, tapi karena sekolah di Methodist akhirnya menjadi Kristen. Istrinya juga Kristen. Orang tuanya tetap beragama Budha. Keberagaman agama di komunitas Tionghoa bisa dilihat sebagai wujud toleransi beragama, tapi di sisi lain juga dampak politisasi yang menimpa komunitas Tionghoa oleh negara.

28 Pengakuan Alex Susanto, tokoh Tionghoa muslim Banda Aceh, 28 Januari 2016. 
dan Langsa. Dari seluruh Aceh, sedikitnya ada 15.000 warga Tionghoa yang eksodus. Di Medan, mereka tinggal di penampungan di Pulau Berayan, Suka Mulia dan Binjai.

Kejadian 1966 itu sangat membekas dan berhasil mengurangi populasi Tionghoa cukup signifikan terutama di Banda Aceh. Catatan Pusat Latihan dan Penelitian Ilmu Sosial Darussalam, Banda Aceh pada tahun 1976, menyebutkan pada 1964 jumlah warga Tionghoa yang tinggal di Banda Aceh sebanyak 6.334 orang. Dari jumlah itu, hanya 750 orang tercatat sebagai warga negara Indonesia. Sisanya, 5.584 orang terdiri dari warga negara Republik Rakyat Cina (RRC) dan kelompok stateless (warga Republik Tionghoa Nasionalis Taiwan). ${ }^{29}$ Salah satu yang menyebabkan komunitas Tionghoa sulit menjadi warga Banda Aceh adalah keharusan membuat SBKRI (Surat Bukti Kewarganegaraan Republik Indonesia) sesuatu yang sudah diberlakukan sejak 1973. Baru pada masa pemerintahan Abdurrahman Wahid SBKRI ini tidak berlaku lagi. ${ }^{30}$

Di era reformasi dan pasca perdamaian MoU Helsinki 2005, kondisi kehidupan etnis Tionghoa menjadi lebih baik. Setelah perdamaian Aceh mereka bisa mengadakan kegiatan yang berhubungan dengan ekspresi kebudayaan dan keagamaan. Sebenarnya sejak era Pemerintahan Abdurrahman Wahid komunitas Tionghoa bisa kembali merayakan Imlek dan Cap Go Meh, tapi di Aceh mereka baru bisa melaksanakan di Banda Aceh pada masa walikota Mawardy Nurdin (2007-2014).

Mawardy Nurdin menjadi walikota pertama yang terpilih melalui Pilkada serentak Aceh pada Desember 2006 dan dilantik untuk periode 2007-2012. Mawardy yang berlatarbelakang teknokrat maju Pilkada saat itu bersama Illiza Sa'aduddin Djamal, anak tokoh PPP Aceh. Mereka maju Pilkada berkat dukungan PPP, PBR, dan Partai Demokrat. Sebagai mantan birokrat, jabatan terakhirnya adalah kepala Dinas Perkotaan dan Permukiman NAD (20032005). Ia dikenal sebagai sosok berpikir maju dan terbuka. Ketika ia menjadi walikota, Banda Aceh tidak memberlakukan pelaksanaan hukuman cambuk seperti kabupaten/kota lain. Ini dilakukan untuk menghindari citra negatif Banda Aceh sebagai pintu gerbang Provinsi Aceh.

Pada tahun 2020, masyarakat Tionghoa memang tidak leluasa melaksanakan kegiatan kebudayaan Imlek dan Cap Go Meh. Namun hal itu tidak hanya dialami oleh komunitas Tionghoa, tapi juga seluruh perayaan hari besar lainnya karena dampak Covid-19. Namun mereka masih dapat melakukan kegiatan yang menunjukkan solidaritas kemanusiaan. Salah satunya adalah kegiatan membuka Warung Murah. Kegiatan ini dilaksanakan sejak 29 Juni - 30 Juli 2020. Kegiatan ini terlaksana karena adanya keprihatinan yang dirasakan oleh masyarakat Banda Aceh karena dampak Covid-19, sehingga kurangnya pemasukan ekonomi. ${ }^{31}$

29 Andi Irawan, "Pecinan Tua Peunayong: Romantisme Sejarah Tionghoa di Aceh", kompasiana.com, 22 Desember 2012. Diperbarui: 24 Juni 2015. Pada saat itu aksi massa untuk mengusir etnis Tionghoa terdepan dilakukan organisasi kepemudaan dan mahasiswa. Menurut laporan penelitian Pasifikus Ahok (1976), pengusiran itu dipelopori oleh Kesatuan Aksi Pemuda Pelajar Indonesia (KAPPI) dan Kesatuan Aksi Mahasiswa Indonesia (KAMI). Aksi ini dibantu oleh Resimen Mahasiswa (Menwa) yang didukung Kodam I Iskandar Muda.

30 Wawancara dengan Yuswar.

31 Serambinews.com, Hakka Buka Warung Murah, Beli Nasi Rp 7.000 di Warung Muslim Dijual Kembali Rp 3.000. diakses dari https://aceh.tribunnews.com/2020/06/29/hakka-buka-warung-murah-beli-nasi-rp-7000-diwarung-muslim-dijual-kembali-rp-3000. 
Warung murah yang dibuka di depan kantor Hakka Peunayong itu melibatkan relawan dari kalangan muslim, yaitu mahasiswa dan juga aktivis keberagaman. Demikian pula makanan yang disajikan berasal dari warung-warung yang ada di sekitar kantor Hakka. Tujuannya agar jangan sampai membunuh usaha kecil masyarakat akibat dibukanya warung murah tersebut. Pihak Hakka membuka donasi bagi komunitas Hakka seindonesia untuk ikut membantu dan kemudian donasi itu digunakan untuk membeli makanan seharga Rp7.000 - 10.000 dan dijual kepada masyarakat seharga Rp3.000. Akibat model penjualan yang "timpang" itu, pihak Hakka harus menutup kekurangan harga beli sekitar Rp1 juta setiap hari. ${ }^{32}$

Aksi solidaritas ini dilaksanakan oleh komunitas Hakka adalah untuk menunjukkan sikap empati etnis Tionghoa akan kesusahan yang dialami masyarakat Banda Aceh. Mereka ingin menunjukkan bahwa semua warga Banda Aceh adalah saudara yang harus dibantu. Kegiatan warung murah ini adalah salah salah satu kegiatan yang dilaksanakan selain membuat masker dan face shield.

Meskipun demikian, keberadaan Tionghoa juga tidak sepenuhnya bisa diterima oleh elite Aceh. Mereka tetap tidak memiliki akses yang sama dengan warga lainnya terkait dengan hak-hak utama warga negara seperti pendidikan dan hak sosial-ekonomi. Padahal di Banda Aceh sendiri ada sekitar 300 KK warga Tionghoa yang terdampak Covid-19 dan tidak mendapatkan bantuan beasiswa pendidikan hanya karena mereka berada di sekolah swasta, yaitu sekolah Methodist dan SMP-SMA Katolik Budi Darma. Walikota Banda Aceh saat ini, Aminullah, dianggap tidak memiliki sensitivitas terhadap keberadaan komunitas minoritas, bukan hanya kepada komunitas Tionghoa. ${ }^{33}$

Masih timbul prasangka bahwa komunitas Tionghoa Banda Aceh sebenarnya tidak benar-benar mau menjadi warga Banda Aceh. Elite di Banda Aceh melihat penggunaan bahasa Mandarin (sebenarnya yang digunakan adalah bahasa lokal: Khek) sebagai penanda bahwa masyarakat Tionghoa Banda Aceh masih bersikap eksklusif. ${ }^{34}$

Hal ini kurang dipahami oleh elite Banda Aceh tentang keberadaan etnis Tionghoa di Banda Aceh. Secara antropologis, komunitas Tionghoa yang berada di Sumatera rata-rata bersuku Khek. Mereka cenderung menggunakan bahasa sub-Mandarin dalam keseharian, berbeda komunitas Tionghoa di Jawa dan Kalimantan yang tidak menguasai lagi bahasa leluhur mereka, yaitu yang bersuku Hok Kian, Hai Nan, Kong Hu, atau etnis minoritas lainnya. Mereka menggunakan bahasa lokal setempat sebagai bahasa ibu. ${ }^{35}$

32 Wawancara dengan Kho Kie Siong, 14 Oktober 2020.

33 Dari penjelasan Pastor Roni, pimpinan Paroki Gereja Katolik Hati Kudus, Banda Aceh, para siswa sekolah BUdi Dharma mendapatkan bantuan paket data internet dari pemerintah. Demikian pula guru-gurunya. Yayasan Budi Dharma sendiri memiliki 12 guru muslim dan berjilbab. Wawancara dengan Pastor Roni OCD, 12 Oktober 2020.

34 Wawancara dengan Arif Fadhillah, anggota DPRA dan mantan Ketua DPRK Banda Aceh (periode 20142019), 13 Oktober 2020. Kesimpulan itu bukan saja bisa dilihat dari pandangan elite pemerintahan di Aceh, bahkan juga penulis sejarah Tionghoa di Aceh. A. Rani Usman dalam bukunya membuat kesimpulan yang lebih kurang sama: "Etnis Cina di Banda Aceh hidup berkelompok dan di dalam keseharian sangat jarang berinteraksi dengan masyarakat pribumi sehingga terkesan tertutup dengan masyarakat setempat" (Usman, Etnis Cina, h. 8). Penggunaan istilah "Cina" dan "pribumi"untuk buku yang terbit pada 2009 menunjukkan sang penulis masih tidak sensitif dengan istilah yang memberikan makna pejoratif dan stigmatisasi.

35 Pengakuan Liling Teja Suyati (A Ling), perempuan Tionghoa Banda Aceh kelahiran Martapura, Kalimantan, tapi besar di Surabaya. Ia ikut suaminya suku Khek ke Banda Aceh. Komunitasnya di Surabaya 
Stigmatisasi ini yang menyebabkan komunitas Tionghoa di Banda Aceh tetap menjadi "minoritas yang berbeda". Tionghoa dikonstruksikan oleh propaganda politik hingga menjadi simbolisasi pejoratif dengan pelbagai labelisasi yang merendahkan identitas sosial mereka.

\section{Komunitas Kristen dan Politik Rumah Ibadah}

Secara populasi, komunitas Kristen tumbuh lintas etnis, meskipun ada gereja Protestan etnis di Aceh. Namun jika digabungkan dengan seluruh komunitas Kristen-Katolik, mereka lah minoritas terbesar.

Di Banda Aceh terdapat tiga bangunan gereja Protestan dan sebuah gereja Katolik. Ada beberapa denominasi Protestan lain yang muncul pada akhir 90-an dan pasca tsunami, tetapi belum memiliki bangunan sendiri. Sejarah Kristen memang lebih muda dibandingkan sejarah Hinduisme (India) dan Budha (China), tetapi kekristenan di Banda Aceh juga telah berbilang abad. Meskipun umur bangunan-bangunan gereja yang ada sekarang baru hadir pada abad ke-20 tapi komunitas Kristen telah ada sejak ratusan tahun lalu.

Sejarah Katolik telah mulai menampakkan jejak sejak abad ke-17. Tepatnya ketika datang dua imam Katolik, Dionisius dan Redemptus, ke Ulee Lheu pada 1638 di masa pemerintahan Sultan Iskandar Tsani. Keduanya ikut bersama kelompok dagang Portugis mengunjungi Aceh dari Malaka. Tetapi keduanya kemudian menjadi martir, tewas dibunuh. Gereja Katolik Hati Kudus di Banda Aceh memperingati setiap 29 November sebagai hari kemartiran mereka. ${ }^{36}$

Menurut Hermanus Saha, pastor Paroki Gereja Katolik Hati Kudus Banda Aceh, mereka dibunuh karena hasutan organisasi gereja Belanda yang Protestan. Padahal dalam sejarah diketahui hubungan Portugis dengan Aceh telah berlangsung sejak abad ke-13 dengan kedatangan Marco Polo pada 1292 hingga kedatangan Giovanni Da Empoli, orang Italia yang kehadirannya ke Aceh membantu pedagang Portugis pada 1524. Hubungan dengan "kerabat lama", Portugis, mulai terusik ketika Belanda sebagai penyebar agama Kristen Protestan mulai akrab dengan Kerajaan Aceh pada masa suksesor Sultan Iskandar Muda itu. ${ }^{37}$ Ketegangan Katolik dan Protestan di Eropa ikut menjalar di dunia-dunia luar yang mereka kunjungi.

Sejarah gereja Kristen di Banda Aceh ini sesungguhnya memiliki keterkaitan dengan dokumen-dokumen historis yang dikumpulkan sejarawan Aceh. Dalam buku Witnesess to Sumatera: A Travellers' Anthology (1995), Anthony Reid, profesor (emeritus) sejarah Australian National University (ANU) yang mengompilasi dokumen-dokumen tua, menemukan catatan perjalanan Jeronymo Dos Reis dan Carlos de N.S. Do Porto Seguro yang menceritakan kaum "Fransiskan di Aceh". Yang dimaksud dengan Ordo Fransiskan ialah ordo Katolik yang melakukan pelayanan di daerah-daerah baru di luar Eropa yang

menggunakan bahasa Jawa sebagai bahasa ibu. Hal itu pula menyebabkan komunitas Tionghoa di Surabaya tidak mengalami kekerasan seperti di Jakarta. Awalnya ia beragama Budha, setelah menikah beralih ke agama suaminya, Katolik. Ia beretnis Hupei. Etnis Hupei di Surabaya kebanyakan bekerja sebagai tukang gigi. Karena A Ling kurang menguasai bahasa Khek, ia kurang leluasa bergaul dengan komunitas Tionghoa di Banda Aceh.

36 Wawancara dengan Pastor Hermanus Sahar (Pastor Paroki Gereja Hati Kudus Yesus Banda Aceh dan Ketua Yayasan Budi Dharma), 30 Januari 2016.

37 Sebagaimana tertulis di dalam situs http://www.imankatolik.or.id/kalender/1Des.html dan dikembangkan dari wawancara dengan Pastor Hermanus Sahar. 
cukup berat karena tidak memiliki akar-akar Katolik dan telah dikuasai oleh kerajaankerajaan Islam. ${ }^{38}$ Kaum Fransiskan terkenal rela berkorban dan hidup melarat. Jika di kalangan Islam mungkin disamakan dengan kaum sufi.

Meskipun demikian, keberadaan gereja Katolik yang ada sekarang tidak memiliki sejarah langsung dengan tragedi abad ke-17 itu. Geraja Katolik Hati Kudus Banda Aceh dibangun pada 26 September 1926. Ini adalah gereja Katolik di Banda Aceh yang didirikan oleh Pastor Henricus Verbraak. Pertama kali berdiri di Sabang pada 1890. Jumlah umat Katolik di Banda Aceh dari catatan baptisan saat ini sekitar 1300-an. Sebagian besar adalah Tionghoa dan Batak. ${ }^{39}$

Pada era Aceh modern, komunitas Katolik sendiri hampir tidak pernah berkonflik dengan masyarakat Aceh. Gereja Katolik Hati Kudus yang terletak hanya 500 meter dari Mesjid Raya Bayt ar-Rahman tidak pernah terusik dan terbakar, berbeda dengan pengalaman gereja Protestan. Di sekolah Katolik, anak-anak yang bersekolah bukan saja anak-anak Katolik, tapi juga Budha dan Protestan. Bahkan di Sekolah Budi Dharma di Takengon mayoritas muridnya adalah muslim.

Di samping keyakinan Katolik “yang lebih pasrah” dibandingkan Protestan, umat Katolik juga minoritas dibandingkan Protestan. Mereka hampir tidak pernah menunjukkan protes terhadap kebijakan Pemerintah Kota Banda Aceh. Bahkan sebenarnya meskipun Syariat Islam di Aceh mereka anggap sebagai panggilan Al Quran dan harus dijalankan oleh umat Islam, umat Katolik masih was-was ketika berada di ruang publik jika tidak menggunakan jilbab dan berpakaian tidak islami.

Demikian pula sejarah Protestan di Banda Aceh, mereka telah menjadi bagian dari sejarah kultural masyarakat Aceh sejak akhir abad ke-16 atau awal abad ke-17. Pelayaran Belanda ke Aceh belajar dari keuntungan yang didapatkan oleh Portugis dan Spanyol dalam menjalankan hubungan dagang ke Nusantara.

Mereka melihat bagaimana keuntungan finansial yang didapatkan oleh Portugis terkait perdagangan emas hitam yaitu rempah: lada, bubuk cabai, dan kayu manis. Kisah itu yang kemudian dirintis oleh Cornelis De Houtman untuk melakukan pelayaran ke Kerajaan Aceh pada masa Sultan Alauddin Riayatsyah (1589-1604), meskipun misi perdana itu tidak sukses. ${ }^{40}$ Sejak itu Aceh terus menjadi pilihan strategis Belanda karena kekayaannya atas rempah-rempah.

Salah satu keberadaan gereja yang "bernuansa Belanda" di Banda Aceh adalah Gereja Protestan Indonesia bagian Barat (GPIB). GPIB berdiri pada 31 Oktober 1948. Ia adalah perwujudan dari De Protestantse Kerk In Westelijk Indonesie. Gereja ini merupakan bagian dari Gereja Protestan Indonesia (Indische Kerk).

GPIB di Banda Aceh dulu merupakan bagian klasis Sumatera dan gereja itu bernama Gereja Protestan Koetaradja. Lokasi awalnya berada di depan Mesjid Raya Bayt ar-Rahman atau depan Kodim 0101 Banda Aceh dan Aceh Besar (sekarang menjad ATM BNI). Dari

38 Anthony Reid (ed), Sumatera Tempoe Doeloe: Dari Marcopolo sampai Tan Malaka (Depok : Komunitas Bambu, 2010), h. 67-68.

39 Wawancara Pastor Roni (Pimpinan Paroki Gereja Katolik Hati Kudus Banda Aceh), 12 Oktober 2020.

40 Harun Keuchiek Leumiek, Potret Sejarah., op cit, hal. 24. 
Indische Kerk kemudian hadir GMIM (Gereja Masehi Injili Minahasa), Gereja Protestan Maluku (GPM) dan Gereja Masehi Injili Timor (GMIT). Ketiga gereja itu kemudian hari membentuk satu gereja dengan nama GPIB. Tujuannya memfasilitasi orang-orang Minahasa, Maluku, dan Timor yang bekerja di bagian Indonesia bagian Barat. ${ }^{41}$

Kehadiran GPIB di Banda Aceh mengalami pasang naik dan pasang surut. Pada awal-awal pembentukannya gereja ini cukup ramai dikunjungi terutama oleh TNI yang bertugas di Aceh dan juga sisa-sisa keluarga Belanda. Setelah Indonesia merdeka dan Aceh memberlakukan praktik keistimewaan Syariat Islam sebagai konsekuensi perdamaian pasca pemberontakan Darul Islam/Tentara Islam Indonesia (DI/TII), mulai muncul protes atas keberadaan gereja di dekat Mesjid Raya itu. Pernah terjadi beberapa kali konflik, mulai aksi perobohan bangunan hingga pembakaran.

Pasca pembakaran, majelis jemaat gereja mencoba merenovasi tetapi tidak mendapat izin oleh pemimpin Aceh saat itu. Namun, di sisi lain keperluan jemaat terutama yang berasal dari tentara mendesak gereja yang terbakar segera dibangun kembali. Baru pada masa Pangdam Bukit Barisan Mayjen Arie Jeffrey Kumaat ketika ia berkunjung ke Banda Aceh, terjadi kesepakatan pembangunan gereja, setelah melihat pasukan TNI beribadah di tenda. Pembangunannya kemudian dilaksanakan di Kampung Mulia dengan membeli tanah vihara milik komunitas Tionghoa pada awal 90an. Pembangunan gereja itu selesai pada 1996. Rata-rata jemaat GPIB ialah keluarga TNI, Polri, dan ASN yang berasal dari Papua, Ambon, Manado, dan Timor. Jumlah mereka saat ini sekitar $90 \mathrm{KK}$ atau 300an jemaat.

Gereja lainnya yang ada di Banda Aceh adalah Gereja Methodist Indonesia (GMI). Jemaatnya sebagian besar beretnis Tionghoa, meskipun juga ada etnis-etnis lain seperti dari Indonesia Timur. GMI juga memiliki jenjang pendidikan sejak PAUD hingga SMA. Keberadaan pendidikan Kristen di GMI tidak hanya diikuti oleh komunitas Kristen Methodist tetapi juga denominasi lain, termasuk agama lain seperti Budha. Konsekuensi hadirnya pendidikan Kristen ini juga menyebabkan sebagian yang pernah mengenyam pendidikan di GMI beralih menjadi pengikut Kristen.

Terakhir, gereja yang memiliki jemaat cukup besar di Banda Aceh adalah Huria Kristen Batak Protestan (HKBP). Dari sejarah tuturan yang disampaikan pimpinan HKBP, gereja ini telah ada sejak 1964, tapi pengikut HKBP telah ada di Banda Aceh sejak 1948. Tidak ada dokumen otentik tentang sejarah itu. Sejarah HKBP sempat rusak karena terkena tsunami. Saat ini HKBP sedang mencoba menarasikan berdasarkan kisah dari orang-orang tua yang sudah berumur 80 tahun. Banyak anak-anak muda tidak mengerti tentang sejarah HKBP Banda Aceh. ${ }^{42}$

Awal pembentukan gereja HKBP adalah melayani komunitas Batak yang ada di Banda Aceh. Pada mulanya pelayanan jemaat menggunakan bahasa Toba. Namun kini bertambahnya jemaat bukan saja beretnis Toba tapi juga etnis-etnis Batak lainnya. Di Banda Aceh tidak terdapat gereja Protestan lain seperti etnis Simalungun, Karo, atau Pakpak, sehingga mereka "terpaksa merumpun" di HKBP. Saat ini jumlah jemaat HKBP

41 Wawancara dengan Pendeta Domidoyo M. Ratupenu (mantan pemimpin gereja Gereja Protestan Indonesia Barat/GPIB Banda Aceh), 31 Januari 2016.

42 Wawancara dengan Pdt Luspida Simanjuntak (pimpinan HKBP Banda Aceh), 27 Februari 2016. 
sebanyak 600an orang dengan $200 \mathrm{KK}$. Lokasi HKBP sekarang adalah pindahan ketiga yang terletak di Kampung Mulia.

Menurut Pdt. Luspita Simanjuntak, pimpinan HKBP Banda Aceh saat itu, gereja ini tidak pernah terdampak konflik. "Selama 50 tahun lebih berdiri, gereja kami tidak pernah diganggu. Sampai saat ini, kami sangat nyaman beribadah di Banda Aceh. Hubungan kami dengan warga sekitar juga terjaga dengan baik." ${ }^{33}$

Namun ungkapan Pdt Luspida ini mewakili sikap "protokoler" di depan kelompok mayoritas. Memakai istilah Irving Goffman, kelompok minoritas yang merasa lebih beruntung dibandingkan minoritas lainnya seperti jemaat HKBP Banda Aceh mencoba membangun interaksi sosial dengan memunculkan diri (the self) senyaman mungkin dengan pemerintah. Ada aktualisasi diri melalui latar depan (front stage) untuk memberi pengelolaan kesan (impression management) di ruang publik. Meskipun kadang itu berbeda dengan panggung belakang (back stage) yang penuh dilema dan kegelisahan. ${ }^{44}$

Situasi seperti ini logis dilakukan minoritas yang sedang merasa tertekan dan tidak memiliki banyak pilihan untuk mengungkapkan pikiran. Pilihan itu pasti akan dilakukan juga oleh komunitas minoritas mana pun yang sedang memperkuat hak-haknya. Dalam konteks ini, komunitas HKBP mencoba menjadi --seperti diistilahkan pengajar filsafat dari John Hopkins University, Thomas W. Simon-- "minoritas positif”, yang meskipun tidak memiliki perlindungan penuh oleh kekuasaan, tapi masih memiliki hak yang diakui oleh kelompok dominan. ${ }^{45}$

\section{Subalternitas India Hindu}

Di antara yang paling meranggas keberadaannya di Aceh adalah komunitas India Hindu. Mereka adalah yang paling kecil secara kuantitas dan pengaruhnya di antara pergaulan minoritas lainnya di Aceh.

Padahal, sejarah migrasi etnis India lebih tua dibandingkan dengan Tionghoa di Nusantara. Bukti-bukti arkeologis menyebutkan, kehadiran etnis India, terutama dari selatan (Tamil) ikut membentuk kultur Hinduisme di Aceh dan Sumatera.

Hasil penelitian Prof. K.A. Nilakanti Sastri pada 1932, berdasarkan catatan Hultzsch, dengan judul "Tamil-Merchant-Guild in Sumatera" menunjukkan sejarah dan bukti-bukti kehadiran "Perkumpulan Lima Ratus" pada prasasti Barus, yang menjadi bukti bahwa komunitas India telah tiba di Aceh paling tidak pada abad ke-11. ${ }^{46}$

Dari Peninggalan nama-nama tempat seperti Indrapuri, Indrapurwa, dan Indrapatra, menunjukkan endapan arkeo-linguistik India telah ada di dalam peradaban awal Aceh. Nama-nama tempat itu tidak diganti hingga sekarang, meskipun Aceh telah menjadi Islam.

43 http://syariatislam.bandaacehkota.go.id/pendeta-hkbp-kami-sangat-nyaman-beribadah-di-banda-aceh/. diakses pada 2 Oktober 2020.

44 Usman, h. 19.

45 Thomas W. Simon, Ethnic Identity and Minority Protection : Designation, Discrimination, dan Brutalization (New York : Lexington Books, 2012), h. 78.

46 Y. Subbarayalu, "Prasasti Perkumpulan Pedagang Tamil di Barus : Suatu Peninjauan Kembali” dalam Claude Guillot (ed), Lobu Tua, Sejarah Awal Barus (Jakarta : Yayasan Obor Indonesia, 2002), h. 17. 
Bahkan ada banyak istilah yang kini telah menjadi Islam berasal dari bahasa India kuno. ${ }^{47}$

Pengaruh Hinduisme dan India telah berlangsung cukup tua di Aceh. Bahkan jejak sejarah keislaman Aceh, tidak langsung berasal dari Timur Tengah, tapi mengikuti jalur dari India. Jalur migrasi grup etnis India bukan saja berasal dari selatan dan timur India (Tamil dan teluk Bengal), tapi juga dari Barat dan Barat Daya (Malabar, Gujarat, Kashmir). Jalur Barat ini melewati laut Arab yang membawa komunitas India muslim.

Di Banda Aceh ditemukan nama Kampung India atau Kampung Keling. Dengan intensifnya hubungan perdagangan dan ekonomi termasuk penyebaran agama, maka keberadaan budaya India di Aceh tidak lagi dianggap asing. Banyak tradisi seni pop di Aceh seperti musik menyadur musik-musik India ke dalam bahasa Aceh. ${ }^{48}$

Yang dimaksudkan dengan kampung Keling adalah Kampung Sentosa, Kecamatan Baiturrahman Banda Aceh. Kebanyakan masyarakat Aceh saat ini memahami bahwa Kampung Kedah adalah Kampung Keling. Di Kampung Kedah sendiri memang dikenal sebagai tempat keberadaan kuil Hindu, yang kini tinggal satu-satunya, yaitu Kuil Palani. Satu kuil lagi telah hancur oleh tsunami dan telah diambil-alih kepemilikan lahannya di masa walikota Mawardy Nurdin. Bekas kuil itu kini berdiri Baitul Mal Banda Aceh.

Saat ini nama Kampung Sentosa tidak ditemukan lagi. Kampung Sentosa berada di antara Kampung Sukaramai dan wilayah yang dulu disebut sebagai Kampung Sentosa. Kampung Sentosa berada di sekitar Taman Putro Phang hingga markas militer. Tiga kampung yang berdekatan yaitu disebut Kampung Tiga (Setui, Sentosa, dan Sukaramai) dulunya dipimpin oleh seorang datuk. Pada tahun 1963 Kampung Tiga dilebur menjadi dua kampung yaitu Kampung Setui dan Kampung Sukaramai. Adapun wilayah Kampung Sentosa yang menjadi pemukiman komunitas India yang kumuh dilebur ke Kampung Sukaramai. Kampung Sukaramai ini juga disebut dengan Blur atau Blover, tempat dulu menjadi komunitas Yahudi Belanda di Banda Aceh. Di kampung ini terdapat pekuburan Belanda, Kerkhoff Petjuet. Termasuk yang dikebumikan di sini adalah Mayor Jenderal J.H.R. Kohler, pimpinan militer Belanda pada tewas pada aksi invansi pertama di Aceh, 14 April 1873. ${ }^{49}$

Adapun Kampung Keudah yang juga dianggap sebagai tempat tinggal komunitas India dan diaspora etnis lainnya ternyata di masa lalu menjadi tempat para tawanan ketika Sultan Iskandar Muda membawa mereka dari Kerajaan Keudah. Sebagian orang-orang Keudah

47 Salah satu wujud yang paling nyata adalah bahasa. Masyarakat Aceh tidak menyebut "salat" untuk ibadah wajib, tapi menggunakan kata "seumayang" (sembahyang). Demikian pula tradisi tepung-tawar yang dalam bahasa Aceh peusijuek (etimologis: mendinginkan) menjadi ritual yang masih dilakukan di Aceh untuk menepung-tawari terutama pada momen-momen hidup dan rezeki, seperti saat kelahiran, sunatan, perkawinan, beli kenderaan dan rumah baru. Demikian pula istilah khanduri untuk pesta yang berangkat dari bahasa India kuno.

48 Salah satunya adalah penyanyi lokal Bergek, yang menyadur "lagu-lagu Hindustan" menjadi lagu pop berbahasa Aceh.

49 Detik.com, "Pohon Kohler Saksi Sejarah di Masjid Baiturrahman Ditebang, Warga Aceh Protes", 21 November 2015. Diakses dari https://news.detik.com/berita/d-3076943/pohon-kohler-saksi-sejarah-di-masjidbaiturrahman-ditebang-warga-aceh-protes. Di dalam pemakaman Kerkoff terdapat sekitar 2200 makam perwira dan serdadu Belanda/KNIL, dan di sana terdapat paling tidak 23 makam Yahudi. Tentang keberadaan komunitas Yahudi di Aceh telah ada dengan terjalinnya hubungan ekonomi antara Kerajaan Belanda dan Kerajaan Aceh sejak abad 17. Lihat Teuku Cut Mahmud Aziz, "Jejak Yahudi di Banda Aceh” di dalam Stanley Edi Prasetyo (ed), Pluralisme, Dialog, dan Keadilan (Yogyakarta: Interfidei, 2011). 
itu adalah orang Keling.

Saat ini umat Hindu India di Aceh telah semakin sedikit. Populasinya tidak sampai 100 orang. Bahkan kuil satu-satunya di Banda Aceh, Kuil Palani, menghadapi sengketa karena keberadaan hotel yang dibangun di samping kuil. Pemilik hotel yang beretnis Tionghoa dianggap mengelabui pemilik kuil tentang peruntukan bangunan yang sebenarnya mirip ruko itu. Pihak kuil sudah menyurati walikota Banda Aceh pada 2015 yang meminta untuk menghentikan usaha perhotelan itu.

Illiza Saáduddin Djamal, Walikota saat itu, tidak meresponsnya dengan menyatakan bahwa pembangunan hotel di samping rumah ibadah tidak melanggar perizinan. ${ }^{50}$ Pandangannya tidak sensitif terhadap komunitas "subaltern" - minoritasnya minoritas, hampir tidak ada yang peduli nasibnya. Pada masa walikota Aminullah (2017-2022) kasus ini masih menjadi kasus status quo dan tidak pernah diangkat lagi. Kasus ini dianggap selesai begitu saja karena protes tidak dilanjutkan.

Beberapa kali komunitas peduli keberagaman menjumpai walikota, tapi belum ada respons konkret. Pihak walikota terlihat gamang akan masalah ini dan cenderung membiarkan. Walikota Banda Aceh, Illiza Sa'adudin Djamal, juga tidak pernah menemui langsung komunitas India. Komunikasi selama ini selalu didelegasikan kepada pejabat lain atau melalui mediasi Ombudsman. ${ }^{51}$

Hal ini menyebabkan komunitas India tidak respek kepada walikota saat itu, Illiza Sa’aduddin Djamal. "Kalau pedagang kecil di Peunayong atas nama peraturan mereka kejarkejar tidak boleh berjualan. Sementara kasus ini atas nama peraturan yang seharusnya ditegakkan (terkait harkat martabat manusia) malah tidak digubris." Mereka sering membandingkan walikota sebelumnya, Mawardy Nurdin (2007-2012 dan 2012-2014) dengan walikota sekarang yang terlihat kurang sensitif pada isu-isu keberagaman dan hak minoritas.

Kondisi ini melahirkan situasi dan kompleksitas psikologi-sosial bagi komunitas India Banda Aceh. Mereka merasa menjadi komunitas level terendah atau dikenal dengan istilah subaltern. Konsep subaltern diperkenalkan pertama sekali oleh Antonio Gramsci, pemikir Marxist Italia, merujuk kepada kelas inferior yang dikuasai oleh kekuatan kolonial yang mengungkung dan menjerat hasrat-hasrat kebebasan warga terjajah. ${ }^{52}$ Oleh Gayatri Chakravorty Spivak, feminis poskolonial, gagasan subaltern ini dikaji secara lebih dramatis dalam perspektif kajian budaya melalui sebuah tulisan berjudul, Can the Subaltern Speaks? ${ }^{53}$ Menurut Spivak, kelas inferior yang menjadi komunitas subaltern itu bukan saja mengalami proses marginalisasi secara ekonomi-politik, tapi lebih dahsyat lagi: direpresi secara kultural.

Situasi ini tentu saja menyedihkan bagi komunitas subaltern. Mereka terdisorientasi dari segala arah. Sebagai pengirim wacana (the sender) mereka dianggap tidak memiliki kesadaran yang penuh. Sebagai penerima wacana (the receiver) mereka delusif, kepada

50 Wawancara dengan Illiza Saaduddin Djamal, Walikota Banda Aceh, 7 Februari 2016.

51 Wawancara dengan Djamal, 7 Februari 2016.

52 Antariksa, "Intelektual, Gagasan Subaltern, dan Perubahan Sosial”, kunci.or.id (22 Juli 2009).

53 Dalam Bill Aschroft (ed), The Post-Colonial Studies Reader (London : Routledge, 1995). 
siapakah sesungguhnya wacana itu disampaikan. ${ }^{54}$

Alegori Spivak ini tepat merujuk kepada komunitas India di Banda Aceh. Kehadiran mereka hampir dianggap tidak ada. Bukan hanya karena populasi mereka sangat kecil dan peran ekonomi-politik mereka hampir nihil jika dihubungkan dengan pertumbuhan sebuah kota, tapi juga wacana mereka tidak diperhitungkan. Protes mereka mudah diabaikan, apalagi diamnya dianggap sebagai persetujuan, seperti kasus hotel yang berdampingan dengan kuil.

\section{Ketidaksadaran Mayoritas, Trauma Minoritas}

Realitas etnografis singkat komunitas minoritas di Banda Aceh menunjukkan bahwa konsep keberagaman yang diidealkan sebenarnya belum terpenuhi. Keberadaan minoritas memang tidak direpresi secara ekonomi-politik-hukum, tetapi mereka dieksklusi dari hakhak sosio-kultural. Salah satunya adalah tidak ada perlindungan yang cukup bagi kelompok minoritas untuk merayakan renik kebudayaannya dan mengekspresikan keyakinannya secara otentik. Masih adanya sembilan gereja yang tidak diakui dan terpaksa melakukan peribadatan diam-diam di rumah atau ruko menjadi salah satu indikator bahwa Kota Banda Aceh masih dilematis disebut sebagai kota keberagaman.

Proyek kampung keberagaman yang dimunculkan pada 2015 yang melibatkan Lakpesdam NU, Hakka Aceh, para keuchiek di Kampung Mulia, Peunayong, dan Laksana itu adalah rintisan kerja sosial di tingkat kampung dan belum tepat disebut mencerminkan representasi Kota Banda Aceh sebagai kota madani, atau kota keberagaman.

Persyaratan Kota Madani sebagaimana galibnya wacana masyarakat madani (civil society) adalah melahirkan partisipasi individu yang secara mandiri mengekspresikan dirinya termasuk dalam melahirkan kebajikan sosial (social virtue). ${ }^{55}$ Hal itu hanya akan terjadi jika pemerintah Kota Banda Aceh bisa berlaku adil dan setara bagi semua warga kota, terutama dalam pengelolaan kebijakan yang berhubungan dengan jaminan pluralisme dan multikulturalisme.

Dalam konteks ini elite pemerintahan Banda Aceh masih melihat ada relasi yang tidak simetris antara masyarakat Aceh muslim dan kelompok minoritas. Kelompok elite politik Banda Aceh merepresentasikan kelompok mayoritas itu sebagai orang lain (the otherness). Akhirnya relasi sosial yang terbangun adalah "ketidaksadaran" bahwa wajar mayoritas mendapatkan keistimewaan (privilege) dan kelompok minoritas mendapatkan tekanan (oppression). Sementara kelompok mayoritas dianggap boleh memiliki hak-hak yang mungkin mereka dapatkan, sedangkan kelompok minoritas harus berbuat sesuai dengan keinginan atau kepantasan dalam pandangan mayoritas. ${ }^{56}$

Ini misalnya terlihat dari pandangan kelompok minoritas yang harus mencari pola komunikasi dan respon yang sesuai dengan pandangan mayoritas. Seperti pandangan Pastor Roni, "Kami mencoba beradaptasi dengan lingkungan di Banda Aceh, karena jika

54 Aschorft, h. 25.

55 Ahmad Suaedy, Gus Dur, Islam Nusantara, dan Kewarganegaraan Bineka (Jakarta : Gramedia, 2018), h. 59.

56 Iris Marion Young, "Together in Difference : Transforming the Logic of Group Political Conflict” in Will Kymlicka (ed), The Rights of Minority Cultures (Oxford : Oxford University Press, 1995), h. 159. 
itu kami lakukan mereka menerima baik kami dan berbangga. Termasuk menggunakan jilbab bagi perempuan Katolik ketika berkunjung ke Dinas Pendidikan Kota atau rapat guru." 57

Situasiinijugasemakinpelikjikadihubungkandengankebebasanberagama.Kompleksitas yang dimiliki oleh komunitas Kristen Protestan yang mempunyai banyak denominasi atau Pentakosta misalnya menyebabkan mereka sampai hari ini tidak memperoleh haknya untuk beribadah. Perizinan untuk membuat rumah ibadah dan pembelian properti tidak mudah dilakukan. Ketidakterwakilan mereka di dalam Forum Kerukunan Umat Beragama (FKUB) juga menjadi penyebab mereka dengan mudah dianggap ilegal secara keyakinan, meskipun mereka diakui sebagai warga negara. ${ }^{58}$ Keberadaan mereka dalam momentum Pilkada dan Pemilu diakui dan mendapatkan hak untuk memilih (vote) sebagai bagian dari identitas individual. Namun ketika mereka menyuarakan kepentingan sebagai identitas kolektif (voice), dengan mudah diabaikan oleh elite pemerintah.

Dalam konteks ini akhirnya terlihat bahwa praktik Syariat Islam di Kota Banda Aceh menjadi dilematis dan kontradiktif. Apalagi ketika dimunculkan mitos "gerejanisasi", bahwa pelaksanaan Syariat Islam dari motif dan praktik tidak diarahkan untuk membangun masyarakat kota yang islami, tapi malah mencari motif kecurigaan dari kehadiran sang lain (the others) sebagai ancaman, seolah-olah kehadiran minoritas adalah ancaman Syariat Islam sehingga tidak ada akomodasi dan pemihakan bagi hak-hak kaum minoritas.

\section{Penutup}

Dari pembahasan di atas terlihat bahwa keberagaman Banda Aceh masih menghadapi kendala dalam mengakomodasi kelompok minoritas, terutama terhadap hak beragama dan kebebasan ruang ekspresi kebudayaan. Di sini terlihat bahwa keberagaman kota Banda Aceh masih terlihat palsu (pseudo-diversity).

Kesan keberagaman Kota Banda Aceh sebenarnya tidak digerakkan oleh kesadaran pemerintah lokal dalam mempromosikan pluralisme dan multikulturalisme, tapi muncul kesadaran warga yang aktif dan sifatnya masih di tingkat kampung. Potensi keberagaman yang dimiliki oleh tiga kampung sadar kerukunan lebih karena heterogenitas kampung itu baik segi agama, etnis, dan preferensi budaya. Ketiga kampung itu (Peunayong, Mulia, dan Laksana) memang berada di jantung kota, dan menjadi pusat bandar dan peribadatan yang sibuk, sehingga mencerminkan seolah-olah seluruh warga kota Banda Aceh sangat toleran.

Bahkan sebenarnya kelompok muslim yang menjadi active citizen dalam mengampanyekan keberagaman dan kebinekaan adalah dari kalangan muda Nahdlatul Ulama. Tidak semua organisasi afiliasi Islam cukup nyaman dengan gerakan keberagaman. Kelompok muda NU inilah salah satu yang berperan sebagai active citizen yang membuka politik puitis dari demokrasi, sehingga menghadirkan fakta egalitarianisme yang tidak membiarkan ada kelompok masyarakat terjerembab dalam situasi nelangsa (pity) dan takut (fear). ${ }^{59}$

57 Wawancara dengan Pastor Roni.

58 Wawancara dengan Leila Juari, (Sekjen Relawan Perempuan untuk Kemanusiaan (RPuK)), 9 Oktober 2020.

59 Derek W.M. Barker, Tragedy and Citizenship : Conflict, Reconciliation, dan Democracy from Haemon to 
Seperti tesis Aristoteles, demokrasi tumbuh dengan kesadaran bahwa semua kelompok berada dalam posisi setara. Proses itu hanya mungkin jika ada situasi memahami rasa sedih sebagai pola untuk saling mengidentifikasi masalah dan memahami. Adapun perasaan takut harus benar-benar dihancurkan sehingga memunculkan situasi keberuntungan bagi semua pihak.

Dalam variasi ini terlihat bahwa situasi di Banda Aceh masih menyisakan sindrom minoritas, yang terlihat bukan saja dari perspektif kaum minoritas tetapi juga dari kaum mayoritas atau penguasa. Dari perspektif kaum minoritas ada perasaan serba kalah (defeatism) yang ditandai hilangnya selera untuk berjuang mempertahankan hak dan lebih memilih melakukan politik akseptansi berlebihan. Mereka begitu pesimis terhadap hidup dan menerima begitu saja takdir sebagai masyarakat kalah. ${ }^{60}$

Adapun kelompok mayoritas hidup dalam ketidaksadaran terhadap eksistensi kelompok lain, sehingga tidak terjadi upaya yang secara sadar menghilangkan perasaan galau, sedih, dan traumatis dari kalangan minoritas. Kelompok masyarakat sipil sendiri juga kurang banyak yang peduli pada isu keberagaman, karena dianggap tidak langsung berpengaruh pada hilangnya eksistensi kelompok atau etnis tertentu di dalam komunitas warga Banda Aceh.

Adapun wacana tentang diskriminasi tidak pernah muncul dalam transkrip dan pola komunikasi publik di Banda Aceh. Pemahaman diskriminasi masih dilihat sebagai ketidakadilan yang dimunculkan secara frontal dan agresif, seperti yang diterima komunitas Rohingya di Myanmar, Aborgin di Australia, atau kaum Negro di Amerika Serikat. Tentu dengan pengandaian seperti itu Banda Aceh jelas tidak termasuk daerah yang minoritasnya terdiskriminasi, padahal kondisi ketika minoritas Banda Aceh tidak nyaman mengekspresikan sikap kebudayaan dan keyakinannya, ia telah berada dalam kondisi terdiskriminasi.

Konsep diskriminasi hanya menjadi transkrip tersembunyi -memakai istilah James C. Scott ${ }^{61}$ - tidak pernah menjadi wacana normal di ruang publik. Jika selama ini tidak muncul ekses dari pemberlakuan Syariat Islam di Banda Aceh dari kaum minoritas, hal itu karena sikap untuk menghindari konflik dan peran media yang tidak meliput.

Namun sesungguhnya di akar rumput praktik diskriminasi itu masih terjadi terutama pada "enkulturasi" simbol keagamaan Islam kepada minoritas. Problem dari berjalannya logika mayoritas di ruang publik ini adalah munculnya upaya stigmatisasi sebagai upaya untuk memperdalam marginalisasi terhadap kelompok minoritas.

Akhirnya terlihat bahwa konsep keberagaman masih menjadi sesuatu yang belum tuntas disematkan kepada Kota Banda Aceh seperti masih kusutnya relasi dengan minoritas. Maka diperlukan kebijakan afirmatif dari walikota sebagai upaya sadar untuk membangun masyarakat Banda Aceh yang madani dan toleran.

Kebijakan afirmatif menjadi niscaya agar kaum minoritas bisa hidup normal dan bersaing secara fair dengan komunitas lainnya. Jika tidak, komunitas minoritas akan selalu

Hegel (New Yok : SUNY Press, 2009), h. 59.

60 H.W. Koch, In The Name of the Volk ( London-New York : I.B. Tauris, 1997), h. 228

61 Lihat James C. Scott, Domination and Art of Resistance (Michigan : Yale University, 1990). 
berada pada hubungan asimetris dengan mayoritas yang berkuasa. Pencapaian yang pernah terjadi di masa walikota Mawardy Nurdin (2007-2014) bisa menjadi titik tolak untuk membangun kota yang ramah dan beragam bagi seluruh etnis, kelompok kebudayaan, dan agama.

\section{Referensi}

\section{Buku}

Aschroft, Bill (ed), The Post-Colonial Studies Reader. London: Routledge, 1995.

Atkinson, Paul, and Martyn Hemmersley, Ethnography: Principle in Practices Third Edition. Oxon: Taylor \& Francis E-Library, 2007.

Barker, Derek W.M., Tragedy and Citizenship : Conflict, Reconciliation, dan Democracy from Haemon to Hegel. New Yok: SUNY Press, 2009.

Crang, Mike and Ian Cook, Doing Ethnographies. London: Sage Publication, 2007.

Guillot, Claude (ed), Lobu Tua, Sejarah Awal Barus. Jakarta : Yayasan Obor Indonesia, 2002.

Koch, H.W., In The Name of the Volk. London-New York: I.B. Tauris, 1997.

Kymlicka, Will (ed), The Rights of Minority Cultures. Oxford: Oxford University Press, 1995.

Leumiek, H. Harun Keuchiek, Potret Sejarah Banda Aceh. Banda Aceh: Toko Mas dan Souvenir H. Harun Kechiek Leumiek, April 2008.

O’Reilly, Karen, Ethnographic Methods. Oxon: Routledge, 2005.

Prasetyo, Stanley Edi (ed), Pluralisme, Dialog, dan Keadilan. Yogyakarta: Interfidei, 2011.

Reid, Anthony (ed), Sumatera Tempoe Doeloe: Dari Marcopolo sampai Tan Malaka. Depok: Komunitas Bambu, 2010.

Reid, Anthony, Perjuangan Rakyat: Revolusi dan Hancurnya Kerajaan Sumatera. Jakarta: Pustaka Sinar Harapan, 1987.

Scott, James C., Domination and Art of Resistance. Michigan: Yale University, 1990.

Simon, Thomas W., Ethnic Identity and Minority Protection: Designation, Discrimination, dan Brutalization. New York : Lexington Books, 2012.

Suaedy, Ahmad, Gus Dur, Islam Nusantara, dan Kewarganegaraan Bineka. Jakarta: Gramedia, 2018.

Sulaiman dkk, Perdagangan, Pengusaha Cina, Perilaku Pasar. Jakarta: Pustaka Grafika KIta, 1988.

Thompson, Paul, The Voice of the Past : Oral History. Oxford: Oxford University Press, 1978. 
Willis, Paul, The Ethnographic Imagination. Cambridge: Polity Press, 2000.

\section{Artikel, Situs, dan Media Massa}

Antariksa, "Intelektual, Gagasan Subaltern, dan Perubahan Sosial”, kunci.or.id, 22 Juli 2009.

Detik.com, "Protes Keras, Banda Aceh 3 Kali Masuk Kategori Kota Tidak Toleran", 12 Desember 2018. Diakses dari https://news.detik.com/berita/d-4339550/protes-kerasbanda-aceh-3-kali-masuk-kategori-kota-tidak-toleran

Detik.com, "Pohon Kohler Saksi Sejarah di Masjid Baiturrahman Ditebang, Warga Aceh Protes”, 21 November 2015. Diakses dari https://news.detik.com/berita/d-3076943/ pohon-kohler-saksi-sejarah-di-masjid-baiturrahman-ditebang-warga-aceh-protes

Fasya, Teuku Kemal, "Bersama Bantuan Aceh Masih Menderita”, Kompas, 24 Desember 2005.

Fasya, Teuku Kemal, “Keberagaman”, Kompas, 31 Desember 2016.

Fasya, Teuku Kemal, "Minoritas dalam Strategi Multikulturalisme”, Kompas, 24 Mei 2011.

Hipwee.com, "10 Kota dengan Usia Paling Tua di Indonesia. Ada yang Sudah Ratusan Bahkan Ribuan Tahun!”, 9 Oktober 2018. Diakses dari https://www.hipwee.com/travel/10-kotadengan-usia-paling-tua-di-indonesia-ada-yang-sudah-ratusan-bahkan-ribuan-tahun/

http://syariatislam.bandaacehkota.go.id/pendeta-hkbp-kami-sangat-nyaman-beribadahdi-banda-aceh/. Diakses pada 2 Oktober 2020.

http://www.bandaacehkota.go.id/p/sejarah.html

http://www.imankatolik.or.id/kalender/1Des.html

Irawan, Andi, "Pecinan Tua Peunayong: Romantisme Sejarah Tionghoa di Aceh", kompasiana.com, 22 Desember 2012. Diperbarui: 24 Juni 2015.

Serambinews.com, Hakka Buka Warung Murah, Beli Nasi Rp 7.000 di Warung Muslim Dijual Kembali Rp 3.000. diakses dari https://aceh.tribunnews.com/2020/06/29/hakkabuka-warung-murah-beli-nasi-rp-7000-di-warung-muslim-dijual-kembali-rp-3000

Setara-institute.org. "Setara Institute : Singkawang Kota Paling Toleran Se-Indonesia," 7 Desember 2018. Diakses dari https://setara-institute.org/setara-institute-singkawangkota-paling-toleran-se-indonesia

Zaky, Ahmad, “Madanikah Banda Aceh?”, acehinstitute.org, 2 Juni 2017. 


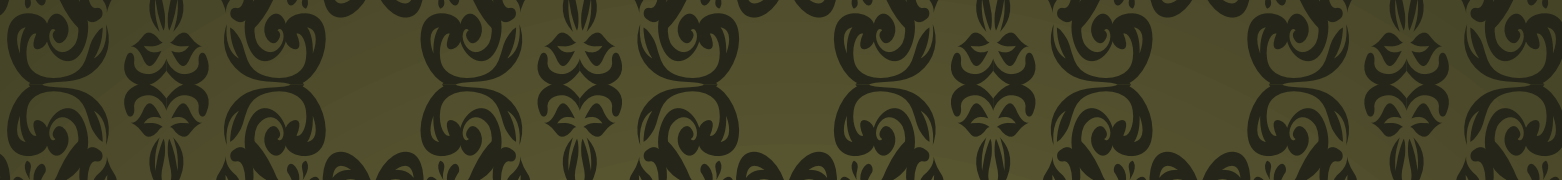

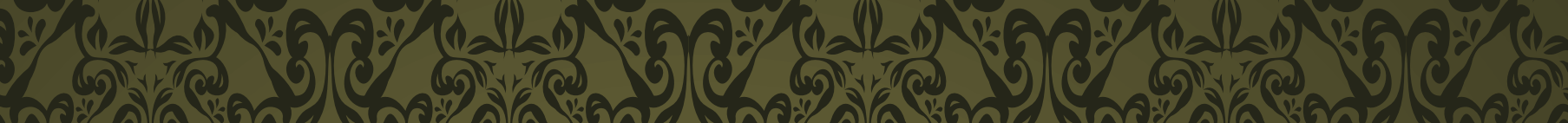

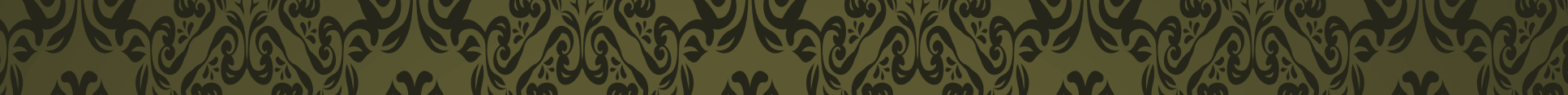

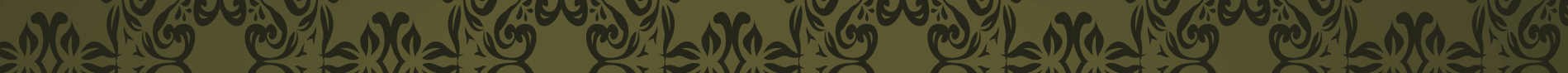

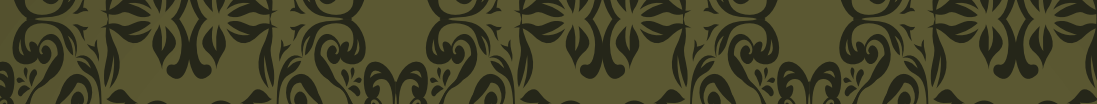

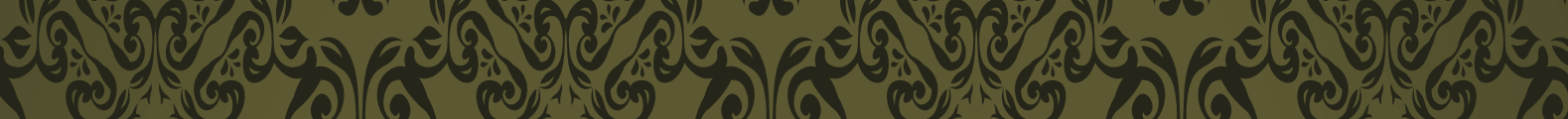

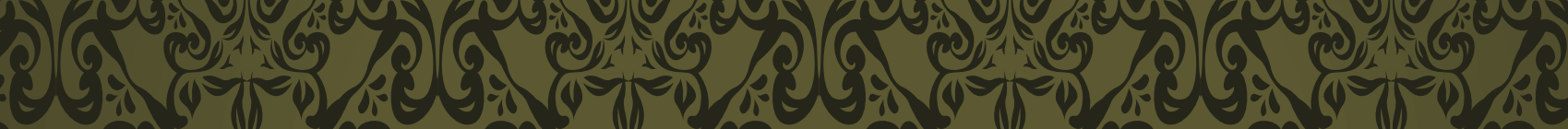
(1)

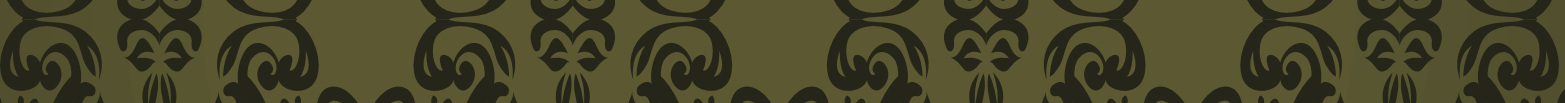

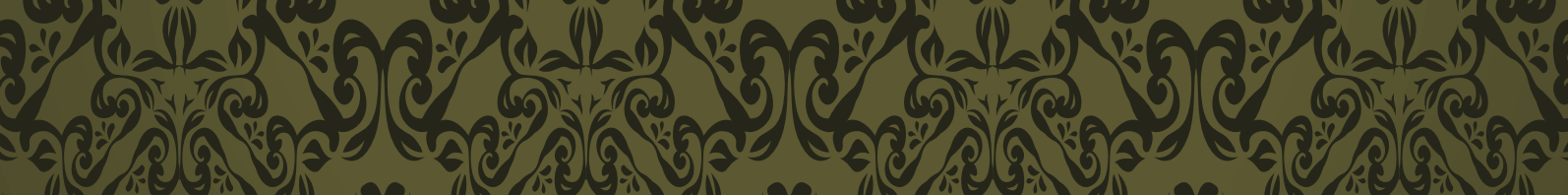

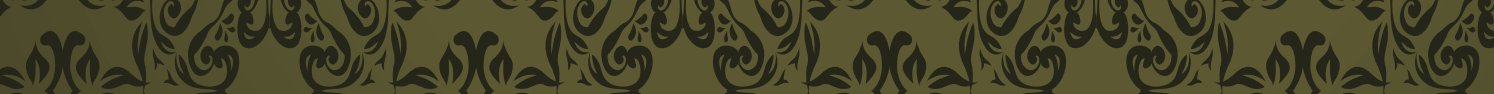
(1) $)(1)$ 5.

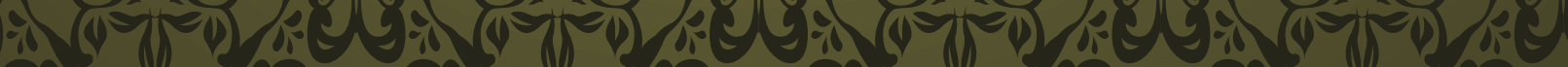

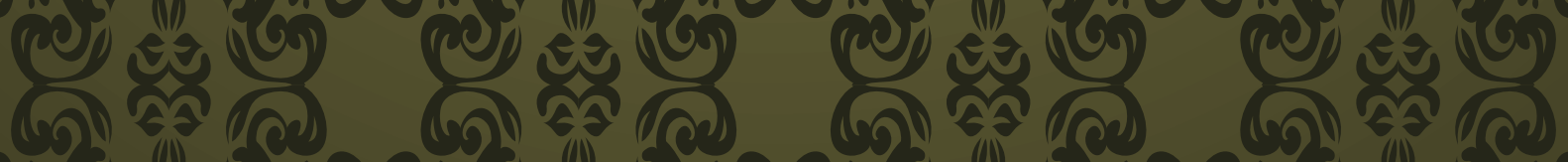

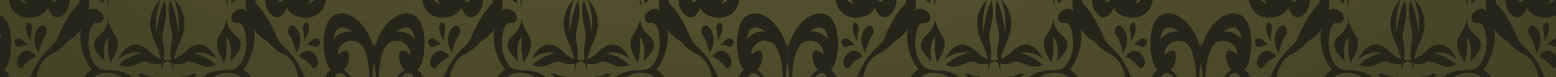
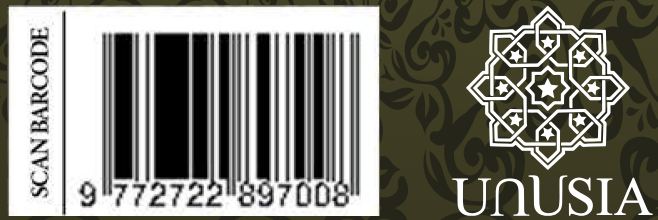

Volume II | E-ISSN 2722-8975

Fakultas Islam Nusantara

Universitas Nahdlatul Ulama Indonesia Jakarta 